\title{
Dynamics of new party formation in the Czech Republic 1996-2010: Looking for the origins of a 'political earthquake'
}

\section{Introduction}

Together with Hungary and Slovenia, the Czech Republic was until recently one of a small number of Central and East European (CEE) democracies, whose relatively closed and stable patterns of party politics made them broad outward approximations of West European type party systems. From its consolidation in 1992-6, the Czech party system, in particular, was characterised by a pattern of stability centred on the continual parliamentary presence of four strong parties with 'standard' political profiles which had integrated relatively successfully with West European party families: the Civic Democratic Party (ODS), the Czech Social Democratic Party (ČSSD), the Christian Democratic Union - Czechoslovak People's Party (KDU-ČSL) and the Communist Party of Bohemia and Moravia (KSČM). Although the Czech political scene was marked by some electoral volatility, this seems largely to have taken the form of voters shifting between these four established actors, rather stemming from the successful emergence of new contenders (Powell and Tucker 2009; Mainwaring et al 2009; Deegan-Krause and Haughton 2010). ${ }^{1}$ A partial exception to this pattern could be found in what might be termed the 'liberal centre' of Czech politics which generated a succession of small short-lived market-oriented parties all seeking in different ways to combine economic liberalism with quality of governance issues such as ecology, decentralisation and civil society development (Pšeja and Mareš 2005; Deegan-Krause and Haughton 2010; Hanley 2010a). Overall, however the Czech party system could be viewed as consolidated and stable one with little scope - or little or no need - for significant new parties to emerge. 
The results of the 2010 Czech parliamentary elections shattered such assumptions. Not only did the support for two main parties slump to historically low levels - the Civic Democrats received their lowest ever national vote, the Social Democrats their worst result since 1992 - but one of the four pillars of the Czech party system, the Christian Democrats, were eliminated from the Chamber of Deputies, the lower house of the Czech parliament. Moreover, in 2010 not one but two new parties, TOP09 and Public Affairs (VV) broke into parliament, taking a combined total of 26.7 per cent of votes cast. As Deegan-Krause notes, in terms of seats and votes, the election thus resulted in highest number of effective parties than at any time since 1992. Adding in the support for small parties which did not cross the five per cent threshold for parliamentary representation, it can be calculated that in 2010 fully 38.5 per cent of the Czech electorate voted for parties formed in the previous two years (DeeganKrause 2010). ${ }^{2}$ Moreover, as Deegan-Krause's extension of Powell and Tucker's calculations (illustrated in figure 1) shows, for the first time there were higher net numbers of Czech voters moving from established parties to new parties, rather than simply 'churning' between established parties.

\section{[FIGURE 1 ABOUT HERE]}

Although levels of volatility and party replacement in the election were well below the regional maximums seen in Central and Eastern Europe since 1989 (Sikk 2005; Mainwaring et al 2009; Powell and Tucker 2009), and, as this article will show, 'new' parties exhibited important personnel and/or programmatic continuities with some existing parties, the prevalent sense among Czech politicians and commentators was that a moment of sudden, unexpected and far-reaching change in the party system 
had been reached. President Klaus, for example, declared the elections to be '... a political earthquake. You could say they haven't left one stone standing on another' (Lidové noviny 2010). ${ }^{3}$

However, the dramatic electoral breakthroughs of TOP09 and VV in 2010 may not entirely have been a bolt from the blue. New parties have been a persistent, if marginal, feature of the Czech party system for many years and it is thus unclear whether the success of TOP09 and VV was unprecedented only because of their levels of their electoral support, or whether their patterns of formation and the type of new party they embodied represented a break with the past. In this article, I seek to put the 'political earthquake' of 2010 into perspective by mapping the development of new parties in the Czech Republic over the past two decades, a period during much of which the Czech party system appeared consolidated or consolidating with new parties being a rare, unimportant or fringe phenomenon. I begin by reviewing the comparative literature on the nature and formation of new parties in Central and Eastern Europe before conducting a detailed review of new parties in the Czech party system and changing patterns of new party development in the Czech Republic since 1996. I then consider possible factors that may have acted as drivers of these patterns, focusing in particular on whether there were common factors underlying both the long period of stability (and new party failure) and the sudden 'earthquake election' of 2010.

\section{New parties in comparative perspective}

\section{'Genuinely new parties'}

The notion of a 'new' or 'genuinely new' party - while empirically necessary to measure party system stability and change - is in many ways problematic. Early 
literature on the subject suggested that 'non-original' parties not present during the formative stage of party system formation should be regarded as 'new' (Harmel,1985: 406) subject to the proviso they actually stood for office and were not alliances of existing parties or existing parties with changed names (Harmel and Robertson 1985: 519, footnote 3). Later authors defined 'genuinely new parties' more rigorously as first time contenders in national elections, again excluding only groupings resulting from re-organisation, merger or coalition of existing parties (Hug 2001; Krouwel and Bosch 2004).

Many authors working on post-1989 new parties in Central and Eastern Europe such as Tavits (2008) retained this definition. Others, however, amended it to allow for the more fluid nature in party organisations in the region and the fact that continuities and discontinuities of party elites were often more telling than continuities and discontinuities of party organisation. Sikk, for example, required that 'genuinely new parties' should not only not be coalitions or merged or rebranded formations, but also that they 'have a novel name and structure and do not have any important figures from past democratic politics among their major members' (Sikk 2005: 399). ${ }^{4}$ However, consistent with his understanding of CEE party systems as (potential) cartels, Sikk also counts as 'new' persistent extra-parliamentary groupings even where they are not first time electoral contenders. Powell and Tucker take a similar approach defining as a 'new' any grouping which newly receives two per cent of the vote after the first or second free elections, thus covering parties that did not exist during early party system formation and persistent minor parties (Powell and Tucker 2009). Such issues of definition raise important questions about how exactly we should understand both 'new' parties and the 'normal' established state of party systems that 'new' parties challenge: should we view new parties essentially as new 
contenders periodically upsetting the equilibrium of dynamic but stable electoral markets, as definitions based on the post-1945 West European experience such as that of Hug (2001) imply? Or should we also see a normal party system as one in a state of continual 'churning' - closer to the experience of CEE - in which yesterday's successful 'new' party contenders become today's 'established' parties and themselves face immediate challenge from newcomers?

\section{Factors underlying new party formation}

Much early discussion based on the experience of West European party systems of the 1970s and 1980s tended to link new party emergence to the rise of new issues stemming in turn from changes in socio-cultural and socio-economic structures. Institutional factors such as electoral systems, while acknowledged, were seen as secondary. Perhaps the best known example of such explanation was the hypothesis explaining the emergence of West European Green parties as based on an expanding left-libertarian constituency of voters with 'post-material' values (Müller-Rommel 1989; Kitschelt 1989). Subsequent work on new parties - less tied to explaining the development of particular party families- tended to give more explanatory weight to institutional factors such as the permissiveness of electoral systems, electoral registration requirements, state funding of minor parties and changes in the competitive environment such as the ideological convergence of established parties (Willey 1998; Hug 2001; Krouwel and Bosch 2004).

Research on new party formation in post-communist democracies tended to further discount the notion of new parties as primarily the expression of new social cleavages or bearers of new issues. Instead, it stressed the role of institutional incentives in opening up opportunities for political entrepreneurs and highlighted conjunctural 
factors such as bouts of public frustration with reform or the widespread perception of politicians in the region as self-seeking and corrupt (Sikk 2005; Deegan-Krause 2007; Pop-Eleches 2010). Even when they appear to be 'standard' programmatic formations, new entrants to post-communist party systems may be thus largely explicable as successful exercises in political entrepreneurship backed by a favourable conjuncture of institutional opportunities, public opinion and existing parties' competitive strategies (Sikk and Andersen 2009).

Both sociological and institutional perspectives on the new parties, however, also arguably need to be supplemented by explanations highlighting the micro-foundations of party emergence: a political party can also be viewed as an organisational solution to a collective action problem, in which participants contribute and exchange a variety of resources (financial, material, technical skills, time, publicity and electoral support) to generate political outcomes (public goods) that would not otherwise be achievable acting on an individual or ad hoc basis (Aldrich 1995; Hopkin 1999). Such perspectives highlight the fact that successful new parties not only need sufficient money, media and human resources, but also that it can offer, as Lucardie (2000: 176) terms it, a 'relevant political project' of interest to potential members and supporters. To emerge a party needs to accumulate sufficient resources and political entrepreneurs need to effectively co-ordinate such exchange by the creating forms of organisation that can overcome collective action problems.

\section{Typologies of new parties}

The debate on sociological and/or institutionally drivers of new party formation is also reflected in typologies of new parties identified in the literature. In a seminal article, Lucardie categorises new parties in Western Europe by origin and self-chosen 
role into three types: prolocutor parties, which represent neglected or unrepresented interests; purifiers, which seek to articulate existing party traditions in more principled and authentic forms; and prophets which introduce genuinely new ideological themes into party competition (Lucardie 2000). Sikk (2005, 2011) however, posits the existence of an additional type of new party, which lacks any clear conventional ideology or chosen constituency, and is instead animated by a vague 'project of newness'. Such party projects, often but not exclusively found in CEE, promise the '...purification of country's politics, for instance, from corruption, while remaining in the ideological mainstream and not anti-system' (Sikk 2011: 3). ${ }^{5}$ As illustrated in table 1, Sikk then integrates the four types of new party appeal into a two-dimensional model defined on one axis by the extent to which appeals are ideological, and on the other by the extent to which they overlap with those of established parties.

\section{TABLE 1 ABOUT HERE}

\section{New party emergence in the Czech Republic}

Identifying new Czech parties

The rich data on Czech political parties makes it a fairly straightforward to identify and categorise new parties. ${ }^{6}$ A more difficult question, however - both for the Czech case and for the study of new party emergence in CEE generally - is the question of when we should take the party system as being formed and which parties we should consider 'established': that is, what baseline we should use to map new party emergence against. More specifically, we need to consider whether we should take the first post-communist elections as 'founding' the party system, or to allow for a longer 
formative period during which established parties consolidated. Given the widely noted character of 'founding elections' as referendums on regime change and the clearly transitional character of the Civic Forum movement which dominated the 1990 election in the Czech lands, I allow for such a formative period which, in common with other authors, I take to be $1990-2 .^{7}$ I therefore classify new Czech parties in the six parliamentary elections from 1996 using the 1992 election as a baseline for identifying which parties were 'established, 8 making two sets of classifications: one following based on new parties' origins, the second on the nature of their political appeals.

I first identify and categorise new parties by origin synthesizing the concepts of parties 'newness' as organisations into three underlying types. This, it should be stressed, is intended a synthesis of existing conceptualisations 'newness', not a worked out counter typology. I thus do not take a position on the nature of party 'genuine newness' or where its boundaries should lie, seeking rather to highlight that the concept of party 'newness' is best seen as graduated and multi-dimensional The three underlying types of organisationally 'new parties' identifiable in the literature are: 1) first time electoral contenders, which have no organisational or personnel links with established parties (henceforth for brevity 'first time electoral contenders'); 2) breakaway parties splitting from established parties (or largely founded by elites breaking away from them); and 3) persistent minor parties, which have previously contested elections, but never independently gained election to parliament. The first two are a subset of the broader category of parties, contesting national elections for the first time. However, given high levels of party merger and fragmentation in some CEE states, few if any authors use a definition unqualified by some indication of organisational or elite continuity. ${ }^{9}$ Conceptually, it is thus not 
possible for a party to belong to both categories 1 and $2 .^{10}$ The third concept, although less common in the literature, follows Schedler's (1996: 299) line of argument that 'smallness and marginality may serve as functional equivalent to novelty'. A summary of 'new' party support in the Czech Republic viewed in terms of this threefold division is given in figure 2. A full classification of 'new' parties and electoral scores can be found in appendix 1

[FIGURE 2 ABOUT HERE]

\section{Patterns of Czech new party development}

If we take 'new' parties by origin, as figure 2 shows, in most elections since 1996 overall electoral support for Czech 'new' parties of all types totals was a consistent 11-12 per cent - the exceptions are 1998, when the Freedom Union entered parliament, and the 'earthquake election' of 2010. However, there is considerable variation across elections in the relative support for different types of new party and only a few clear trends. First, as figures 3 and $\mathbf{4}$ show, there was a spike in the numbers of new first time contenders in 2002, which (although since declining) have continued a relatively high level since suggesting that new party formation has become an attractive strategy for political entrepreneurs.

\section{[FIGURES 3 AND 4 ABOUT HERE]}

Second, compared to other types of new party formation, new breakaway parties are relatively rare in Czech politics and have declined rapidly in number since the initial stabilisation of the Czech party system. As figure $\mathbf{3}$ shows, only six breakaways can 
be identified after 1996, suggesting that, at least in formal organisational terms, both established and minor parties had a high degree of continuity and stability. However, when they do emerge from established parties - as with the formation of the Freedom Union created in 1998 by political opponents of the then Civic Democrat (ODS) leader and outgoing Prime Minister Václav Klaus, many of whom were cabinet ministers or parliamentarians - new breakaway parties often have immediate electoral success. Similarly the leadership of TOP09, the larger of the two new parties breaking through in 2010, was largely composed of prominent former Christian Democrats and its leader was the current Czech Foreign Minister, Karel Schwarzenberg, a diplomat n independent politician with an aristocratic background closely associated with former President Havel first brought into ministerial office in 2007 as a nominee of the Green Party. $^{11}$

Third, and following from this, it is clear that resources and political experience were more important for success than the pure novelty of being a first time electoral contender. Across the five elections in 1996-2010 new electoral contenders were (narrowly) outperformed by persistent minor parties, which were in turn outperformed by better resourced. Pooling performances across the five elections the mean vote for new first time contenders was 0.73 per cent, while persistent minor parties polled a mean vote of 0.85 and new breakaways 4.53 per cent. Median scores which allow better for the influence of a few atypically highly successful new parties show a similar picture: new first time contenders' median vote was 0.2 per cent, while persistent minor parties gained a median 0.29 percent and breakaways 1.4 per cent. Expressed differently, only 8.5 per cent of first time contenders gained 1.5 per cent or above - the current threshold for state funding of electoral expenses in the Czech 
Republic - while for persistent minor party lists the proportion was 17.2 per cent. Fully 42.9 per cent of new breakaways (three of sever cases) achieved this.

This suggests that, at least in the Czech context, any trade-off between the benefits of inherent novelty and the recognition, credibility resources and skills offered by preexisting organisation and 'recycling' experienced politicians is heavily weighted towards the latter. This reinforces the argument that 'newness' is best understood as a political or programmatic project, rather than something based on more objective measures of newcomer or outsider status. Moreover, the very limited advantage persistent minor parties enjoyed over new contenders emphasises what a hostile environment the Czech party system historically represented for enduring extraparliamentary parties and suggests that for resource-poor political entrepreneurs a long, slow strategy of party building from the grassroots yielded few dividends.

\section{The political appeals of Czech new parties}

If we attempt to categorise 'new' parties in the Czech Republic by political appeals in terms of Sikk's two-dimensional re-working of Lucardie's typology, as table 2 shows, it is clear that by far the most electorally and significant parties were 'purifier' parties of the centre or centre-right seeking to offer an improved or reformed form of the conservative or liberal conservative ideology of established Czech centre-right parties. $^{12}$ The three principal centre-right 'purifiers' were the Democratic Union, Freedom Union (US) and TOP09. These parties' appeals stressed distinct quality of governance themes such as civil society development and ethics in public life and stressed their newcomer credentials when competing against established parties whose reform aspirations had (supposedly) become bogged down by corruption and attitudes inherited from the communist past. ${ }^{13}$ However, all three parties sought 
primarily to present themselves as mainstream centre-right groupings offering more genuine forms of conservatism or liberal-conservatism than established parties such the Civic Democratic Party or Christian Democrats, which could act as a corrective to these parties' failings in transforming the Czech Republic into a modern West European-style market society (Pšeja and Mareš 2005). Perhaps unsurprisingly, the two most successful 'purifiers', the Freedom Union (US) and TOP09, were also relatively well resourced 'breakaway' parties, whose founders and leaders were leading politicians in established parties.

Interestingly, there were no significant 'purifier' parties of the left or centre-left, offering a reformulated communist or social-democratic project. The only political formations on the left which seem to fit this category were small, ill-fated parties founded by reformed-minded Communists in the mid-1990s (the Left Bloc (LB) and Party of the Democratic Left (SDL)) which attempted to offer a 'democratic socialist' alternative to conventional social democracy and the orthodox communist position of the Communist Part of Bohemia and Moravia (KSČM). ${ }^{14}$ This imbalance in the supply of 'purifer' parties may reflect the presence of two medium-large established parties on the Czech left competing for a similar electorate with programmatic appeals centring primarily on distributional issues linked to economic management and the welfare state (Kopeček and Pšeja 2008). ${ }^{15}$

Perhaps unsurprisingly in a relatively recently consolidated party system, Czech new parties include few unambiguous examples of 'prophet' parties offering ideological themes distinct from those of established parties. The Czech new parties which mostly closely qualify as 'prophets' are the Green Party (SZ), small radical right 'groups which emerged following the collapse of the parliamentary far-right Association for the Republic-Republican Party of Czechoslovakia (SPR-RSČ) in 1998, including the 
Workers Party (DSSS) which contested the 2010 election, and certain eurosceptic groupings (Mareš 2005a). Far-right 'Republican' groupings including the SPR-RSČ and its successors were clearly spokesmen for distinct nativist radical right populist ideologies (Mareš 2003; Hanley 2010b). However, the Czech Green Party lacked any semblance of the ideologically distinct left-libertarian profile characteristic of West European Green parties until the entry of NGO and social movement activists into the party in 2001-2. Even after this transformation, the party's position was in many ways closer to the qualified market liberalism of reformist centre-right 'purifier' parties discussed above than to West European Green parties (Pečínka 2003; Kopeček 2005a). The party's distinct ecologist critique and identification with one of the major new European party families suggests, however, it could tentatively or weakly be classed as a 'prophet' party. ${ }^{16}$ New eurosceptic parties, which see the defence of Czech interests against the EU as a new ideology transcending left-right divisions also seem classifiable as 'prophets'. ${ }^{17}$ The most prominent current example of such a eurosceptic 'prophet' is the Sovereignty bloc created in 2009 by former newsreader and independent MEP Jana Bobošíková (Suverenita n.d.; Hanley 2011.)

'Prolocutor' parties which seek to represent neglected interests or issues appear a weak and declining element in the supply of Czech 'new' parties. The clearest example of such a grouping is the Pensioners for a Secure Life grouping (DŽJ) which emerged as minor party in 1992 and sustained itself as an extra-parliamentary party by crossing the three per cent threshold for annual state funding - in two subsequent parliamentary elections, before collapsing after electoral failure in 2002 (Kopeček 2005b). A second enduring 'prolocutor' were Moravian regionalist parties, which sought autonomy and enhanced recognition for the historical provinces of Moravia and Silesia. Despite considerable early electoral success and parliamentary 
representation in 1990-6, they have since declined to the status of persistent minor parties (Mareš and Strmiska 2005).

'Project of newness' parties competing with established parties on the basis of vague (but non-extreme) anti-establishment promises of change seem to represent a more dynamic and (relatively) successful new party type in the Czech Republic. The first group of Czech new parties which seem to fall in the 'project of newness' category are groupings of self-styled non-partisan independents. Locally based independents' groupings have been a persistent feature on Czech electoral landscape at sub-national level and have sometimes coalesced into small national level parties (Mareš 2005b; Jüpter 2008). The most electorally important of these was the Nezávislí grouping which evolved into the Independent Democrats (NEZ) led by the former director of the Nova TV station, Vladimír Železný and the Association of Independents (SNK), which won respectively two and three MEPs in the 2004 European elections Although such groupings draw on well-established Czech traditions of localism and non-partisan engagement, they also clearly fit Sikk's 'project of newness' category in combining mainstream views in a vague anti-establishment, anti-political rhetoric of change and renewal. ${ }^{19}$ However, unlike the 'project of newness' parties Sikk (2011) identifies in the Baltic context, such groups project their newness less by claiming pure outsider status, than by stressing the need to import non-ideological expertise, approaches and elites from spheres such as business, education and local politics into national party politics. As Schedler (1997) suggests, advocating the 'colonisation' of the political sphere in this way is represents a weak form of anti-politics as well as an anti-establishment appeal.

However, the party which fits the 'project of newness' category most closely is the Public Affairs (VV) grouping led by former investigative reporter Radek John, which 
emerged from political obscurity in the second half of 2009 and experienced a rapid surge in support, entering parliament in June 2010 with support of over 10 per cent. Although founded as a Prague-based group (in 2002) whose activities were largely confined to municipal politics, following the entry into the party of the businessman Vít Bárta and a group of associates linked to him or the ABL security company he owned, VV eschewed the independent and localist appeals characteristic of regional parties, in favour of vague, but clearly programmatic stance centring on anticorruption, direct democracy, reform and renewal (MFDnes 2011; Kmenta 2011). themes serving as classic building blocks for 'project of newness' parties in the Baltic states and elsewhere in CEE (Sikk 2009, 2011). As well as recruiting a well known non-party-political public figure such John to lead it (in 2009), VV also sought to project novelty and openness through radical organisational innovations such as allowing registered sympathisers to vote on party policy in regular online referendums and heavy promotion of female candidates in its well-funded advertising (Lauder 2010). A further, less significant, new party that seems, albeit less clearly, to fit the 'project of newness' category is the Citizens' Rights Party - Zemanites (SPOZ). Although and led by former Social Democrat leader Miloš Zeman and advocating centre-left socio-economic policies, the party made no effort to project itself as a 'purifier' party, correcting the deficiencies of the established Social Democratic Party, laying its programmatic stress almost entirely on the need to 'change politics', represent politically discontented citizens, and fight corruption by introducing elements of direct democracy such as referenda and the direct election of mayors and regional governors (Strana práv občanů - Zemanovci n.d.).

\section{Changing new party appeals}


In practice many, if not most, 'new' parties in the Czech Republic mix elements of the four ideal types of new party appeal, or in some cases overlap them. In some cases 'new' parties arguably move between types of appeal as they develop. As a nonpartisan alliance of local politicians, the Association of Independents (SNK) for example was, for the reasons explained above, categorisable as a 'project of newness' party in 2002, when it first contested national parliamentary elections. However, SNK's successful electoral alliance with the European Democrats $(E D)^{20}-$ which polled 11 per cent in the 2004 European elections - and its subsequent merger with ED under the leadership of the former prominent ODS politician and former Foreign Minister Josef Zieleniec led to the adoption of a conventional programmatic stance of Europhile market liberalism characteristic of Czech centre-right 'purifier' parties.

What is striking, however, is how in the context of stable programmatic party system with a single dominant (socio-economic) issue dimension (Deegan-Krause 2006), the most successful new Czech parties are 'purifiers'. Moreover, new parties making other types of political appeal tend to lean towards the 'purifer' category, rather than fashioning new ideological positions (as 'prophets') or relying entirely on a radical 'project of newness' anti-establishment rhetoric of renewal. Even recently formed parties 'project of newness' parties such as Public Affairs (VV) and the Citizens' Rights Party SPOZ incorporated familiar programmatic elements of left and right pro-market policies in healthcare and a ban on former members of the Communist Party joining in the case of $\mathrm{VV}$, demands for economic stimulus through public spending in the case of SPOZ.

\section{Changing logics of Czech new party formation}


Parallel trends are observable in the ways in which new parties have mobilised resources and solved collective action problems. Over the past decade few new Czech parties have been launched in the form of full-blown national party projects as occurred earlier in the 1990s with groupings such as the Moravian regionalists (HSDSMS), Pensioners for a Secure Life (DŽJ), the Republicans (SPR-RSČ), or the Democratic Union (DEU). Instead, more successful new parties have increasingly needed to pass through an extended incubation phase of resource accumulation, as what Hug (2001: 14-15) terms a 'potential party'. This stage either takes the form of recruiting a cohesive, credible national-level elite, or of building up organisational presence and credibility locally as a grassroots municipal or regional grouping. In some cases, both strategies have been deployed simultaneously, or in rapid sequence. TOP09, for example, initially emerged in 2009 as a classic breakaway party based on elite networks of Christian Democrat politicians and businesspeople brought together by the former Christian Democrat leader Miroslav Kalousek. However, the new party rapidly sought to acquire a grassroots dimension by forming an alliance with the Mayors and Independents (Starostové a nezávislî) movement formed through the merger of successful independent groupings following the 2008 regional elections (Starostové a nezávislí 2009). The same sequence occurred in the case of Public Affairs, which formed as a Prague-based municipal party, but then sought to recruit experienced politicians and well known public figures to bolster its national leadership, mostly notably its leader, the former investigative journalist and television presenter, Radek John. ${ }^{21}$ These two patterns of pre-party building loosely correspond to Panebianco's classic distinction between party formation through top-down 'territorial penetration' and party formation by horizontal 'territorial diffusion' when 
'...local elites construct party organisations which are only later integrated' (Panebianco 1988: 50).

An additional element of new party formation highlighted by the Czech case, not fully captured in the existing comparative literature, is the role of small local parties and persistent extra-parliamentary groupings in acting as institutional shells awaiting 'capture' and subsequent re-launch by outsiders entering the political sphere. The Green Party (SZ), for example, was for many years a moribund force with few connections to environmental activists and a nondescript programme of piecemeal environmental protection and (sometimes illiberal) demands for law and order and greater social welfare. Only after ecologists and social movement activists took a conscious decision to join the party en masse in 2002 and take over its leadership into, did it acquire the recognisably 'green' political profile described above (Pečinka 2003). Similarly, in the first four years of its existence Public Affairs functioned

purely as a local party with activities confined to three Prague boroughs. Only with the entry of a group of wealthy supporters bringing significant resources in $2005 \mathrm{did}$ it emerge in its current form (iDnes 2010). Filling the organisational 'shell' of a weak or moribund small party may allow political entrepreneurs entering the party-political arena to dispense with the initial registration formalities ${ }^{22}$ and provide a ready made political identity and framework for collective action.

\section{Drivers of Czech new party formation}

What does this suggest about the causes of changing patterns of Czech new party emergence success in the Czech Republic? And how can such change this be squared with the prolonged stability of the Czech party system before 2010? Three broad types of explanation can be culled from the literature: 1) structural explanations 
stressing the robustness and stability of established Czech parties; 2) conjunctural explanations related to configurations in the party system; and 3) institutional explanations relating, in particular, to changes in the party financing regime and the number of 'second order' elections.

\section{Legacies, cleavages and the robustness of established parties}

At one level, the weakness or success of new parties can be viewed as simply the obverse of the robustness of established parties. New parties, it can be argued, will emerge to fill political and electoral vacuum when existing parties fail. Robust established parties, able to maintain themselves organisationally and politically will be well placed to out-compete newcomers - especially over the longer term - and to recover when hit by internal splits, scandal or bouts of electoral unpopularity.

Two distinct structural factors which might underlie the robustness of established parties can be identified in the Czech case. ${ }^{23}$ First, the unidimensional nature of Czech party competition - which has strongly and consistently centred on distributional conflicts - may have constrained opportunities for successful new party emergence by reducing the number of issues that new parties can easily take up: while it is possible for politicians to use agency to bring about realignments or build new electoral alliances from a new 'mosaic' of crosscutting cleavages, this is a highly demanding and difficult task often more easily accomplished by established parties (DeeganKrause 2006; Deegan-Krause and Enyedi..2010). ${ }^{24}$

While cleavage approaches may explain the initial stability of the Czech party system compared to others in the CEE region, it offers no plausible explanation for trends in new party development across time. To address this puzzle, Deegan Krause and 
Haughton (2010; see also Deegan-Krause 2007), for example, suggest also the existence of a 'floating' (and usually latent) anti-corruption (or elite-mass) issue dimension in political competition that has become newly salient, fuelling the rise of a series of short-lived new parties, whose appeal rapidly degrades after initial electoral success and, in particular, entry into government (Deegan-Krause 2007; DeeganKrause and Haughton 2009). However, there is little evidence of the development of new cross-cutting cleavages or dimensions in Czech party competition and, if present in latent form, we are still left with the question of why it should suddenly have become salient.

A second potential explanation can be found in the Czech lands' history of 'partyness' and experience of interwar party democracy may have left legacies, which survived the communist period, allowing established parties to develop clearer programmatic identities, grassroots organisation and more sizeable electorates after 1989. Of the four most well established Czech parties over the past twenty years, three (the Christian Democrats (KDU-ČSL), Communists (KSČM) and Social Democrats (ČSSD) were 'historic parties' with political roots going back to the pre-communist period able to draw on a loyal (if small) core electorates of party identifiers at the outset of democratic competition in 1990. . Two (KSČM, KDU-ČSL) were also able to draw directly on organisational resources inherited from the period of communist one party rule.(Pšeja 2005).

However, these organisationally robust successor parties were relatively minor actors in the Czech party system which largely failed to expand beyond niche electorates. Moreover, it is hard theoretically convincingly to specify mechanisms through which deep historic legacies might have been transmitted and operated. ${ }^{25}$ This leaves only the argument that established parties stabilised because they were able to build on 
their initial advantage of being better organised and better supported during the immediate post-transition period formative stage of party politics. Moreover, the existence of better placed early front runner parties was hardly unique to the Czech Republic. In the CEE post-communist context other than voters' 'adaptive expectations' and disproportionate levels of state funding for parliamentary parties, there were few plausible 'lock in' mechanisms explaining how such front runners could generate 'increasing returns' from initial success so to exclude new competitor parties. As has been widely noted, classic mechanisms of party- and party system 'freezing' such as the encapsulation of key constituencies through mass social organisation; the growth of partisan loyalties among voters; or the clientelistic provision of selective benefits to key electoral constituencies are weak or absent in Central and Eastern Europe (Hanley et al 2008; Kreuzer 2009; Deegan-Krause and Enyedi 2010). Such expectations were confirmed empirically by the failure of many Central and East European states to progress beyond fluid party systems with many openings for successful new party emergence. This suggests that in the case of the Czech Republic, factors affecting the 'supply' of credible and effective new parties, rather than shifts in underlying voter 'demand' for new parties or the historically conditioned robustness or established parties may be key to understanding patterns of new party (non-) success.

\section{Party system conjuncture}

Linek suggests that the proliferation of new parties after 2002 reflected public disaffection with the 'Opposition Agreement', the pact signed in 1998 by the Civic Democrats (ODS) and Social Democrats (ČSSD) allowing a minority ČSSD government to take office (Linek 2002: 128). However, this interpretation sits 
uneasily with the continued trend for new party emergence in 2006 election, a period of sharp polarisation between the two main parties when both gained record votes (Hanley 2006). The 1998-2002 period does seem to represent a type of conjuncture favourable for a certain type of new party with good potential for success: the 'breakaway' grouping.

1998 saw the Freedom Union break away from Civic Democrats and -in reaction to the signing of the Opposition Agreement - to form the Quad Coalition (Čtyřkoalice) alliance with two small established parties, the Christian Democrats (KDU-ČSL) and the Civic Democratic Alliance (ODA), and the extra-parliamentary Democratic Union (DEU) party. ${ }^{26}$ Similarly, the period leading up to the 2010 election coincided with a period of declining popularity for both main established Czech parties at a time when they were again collaborating in government in an unusual way: on this occasion supporting a caretaker government of non-party technocrats formed to lead the country to early elections. In 2010, as in 1998-2002 (Roberts 2003), acute factional divisions in an established party combined with unpopularity of the two established major parties, seems to have offer the key incentive for politicians within an existing established party - bolstered by a sense of national political drift and stagnation - to form successful new breakaway party: the impetus for the formation of TOP09 came from a group of pro-market modernisers in the Christian Democratic Union (KDU ČSL) led its former leader Miroslav Kalousek.

\section{Changing financial incentives for new parties}

Since 1994 all Czech parties receiving at least 3 per cent of the vote nationally in elections to the Chamber of Deputies have received a small capped annual public 
subsidy based on the number of votes received. Parties also receive a one-off votesrelated payment following elections to the Chamber to cover campaign expenses. The threshold for this was also initially set at three per cent of the national vote, but in 2002 the threshold was lowered to 1.5 per cent following repeated Constitutional Court rulings that higher thresholds violated constitutional principles. Moreover, at the same time a new system of a non-refundable 'election fees' replaced deposits, considerably lowering the cost of contesting elections for small, poorer new parties and, in particular, for new first time contender parties, which proliferated from 2002 (Linek and Outlý 2008). ${ }^{27}$

\section{Second order elections}

A further significant change in opportunity structures facing parties has been the gradual development of a raft of 'second order elections' in the Czech Republic to a number of countervailing, sub-national and European institutions: the Senate (first elected in 1996), regional authorities (first elected in 2000) and the European Parliament (to which Czech MEPs were first elected in 2004). In such 'second order elections' voters are generally more willing to consider voting for new parties (often as a form of protest), and results are rendered more unpredictable by low turnouts. Second order elections also represent an additional - and, in some cases, more easily accessible - source of public funding. ${ }^{28}$ However, the precise nature of incentives and which type of new parties they benefit - varies by institution.

For example, the localised nature of Single Member District contests to the Czech Senate and absence of any national threshold for representation enables small 'new' parties to their concentrate their limited resources more effectively, focusing on localities where their chances of electoral success may be higher. Senate elections 
thus provide strong incentives for new parties (often persistent minor parties) and well placed individual independents- usually popular local politicians, sitting senators who no longer have a party affiliation or prominent figures in public life - to work together. Nomination by a registered political party frees an independent candidate from the need to gather 1000 signatures, confers a recognisable programmatic political identity and may additionally bring some level of organisational and financial support. For a small 'new' party gaining a candidate who is personally prominent and/or has a strong local base - hence and has a reasonable prospect of being elected - enhances a party's political profile and credibility, as well as bringing it annual state funding if 'its' candidate is elected. ${ }^{29}$ The election of the war correspondent and human rights activist Jaromír Štětina as a senator nominated by the Green Party (SZ) in 2004, for example, was widely seen as important in enabling SZ establish the political momentum, which helped it enter the Chamber in the 2006 elections (Kneblová 2009).

Elections to the Czech Republic's 13 regional authorities, ${ }^{30}$ first held in 2000, constitute a further set of 'second order' electoral opportunities for new parties, albeit specific and narrower opportunities than elections to the Senate and European parliament. The smaller (regional) scale of these contests coupled with the use of 5 per cent regional threshold for representation should, in principle, again offer opportunities to 'new' parties able concentrate electoral support and political organisation in certain parts of the country. ${ }^{31}$ At 15,000 crowns per region (€500$€ 600)$, a sum equivalent to approximately a month's average salary in 2000 when regional elections first took place, fees payable do not pose a significant financial obstacle to new parties. Regional representatives (unlike municipal representatives) 
are also a source of an annual state subsidy of 250,000 crowns (currently approximately $€ 10,000)$ for the parties nominating them.

Across the three sets of regional elections in the Czech Republic (2000, 20004, 2008) non-parliamentary parties and independents were consistently able to benefit from these opportunities, having gained representation in the majority of regional authorities in every election since 2000. However, the scale of such representation has been limited, typically numbering $30-50$ of the 675 regional representatives elected across the Czech Republic. As illustrated in figure 5, which gives the absolute numbers of regional representatives elected for minor (non-parliamentary) parties, regional groupings and independents, there has been no marked upward trend in representation of non-established parties at regional level, suggesting that the organisational and resource demands of region-wide campaigning are simply too challenging for many small 'new' parties. This is indirectly confirmed by examining the type of challenger parties gaining representatives in regional elections: with the partial exception of 2004, independents' groupings have proved markedly more successful than non-parliamentary parties.

\section{[FIGURE 5 ABOUT HERE]}

This is unsurprising given that such groupings usually originate as alliances of influential non-aligned local politicians or mayors, who have already gained a degree of grassroots support (Mareš 2005b). This therefore suggests that the regional elected tier in the Czech Republic represents an opportunity - and a route to party formation for only one type of 'new' party: 'project of newness' parties making non-political (or anti-political) appeals based on the experience of sub-national politics. Close 
analysis of regional election results suggests that there may be a certain cyclical element to the development of such groupings. ${ }^{32}$

A similar function was played by elections to the European Parliament which have been held twice in the Czech Republic - in 2004 and 2009. As with elections to the Chamber of Deputies, parties need to meet a formal threshold of 5 per cent of the national vote to gain representatives. ${ }^{33}$ Despite this, on one occasion the 'second order' character of the elections and the presence of an unpopular mid-term government allowed new parties to gain representatives: in 2004 Association of Independents Lists - European Democrats (SNK-ED) gained 11 per cent (and two MEPs) and the Independent Democrats 8.8 per cent (and two MEPs). This success positioned both parties as more credible (and better financed) challengers in the 2006 Chamber elections, although neither proved able to break through electorally. Similarly, although more mutedly, the surprisingly high 2.4 per cent polled by Public Affairs (VV) in the 2009 European elections - the first time the party had contested a nationwide election.

Perhaps equally significant are the relatively low financial obstacles to participation and state funding in European election. Moreover, at 15,000 crowns (currently around $€ 600)$ for each full electoral list, the charge levied on parties is by far the lowest for nationwide election in the Czech Republic. A one-off subsidy to cover election campaign expenses is also paid to parties contesting European elections, which receive more than 1 per cent of the national vote, a lower threshold than applies for the equivalent subsidy in parliamentary elections. In the 2004 European elections three parties which polled less than five per cent of the vote, qualified for such subsidies: of these, the Greens, the Right Bloc (PB) and the Union of Liberal Democrats (ULD). ${ }^{34} \mathrm{~PB}$ and ULD polled less than 1.5 per cent - a level of support 
which would not have qualified them for campaign subsidies in elections to the Chamber of Deputies. Similarly, in 2009 excluding the Greens (already a parliamentary party) seven parties with less than five per cent qualified for subsidies. Of these five polled less than 1.5 per cent. ${ }^{35}$

The 2009 European elections served as a spur for new party formation. Ideological disputes within the Civic Democratic Party over ratification the Lisbon Treaty led to the creation of the eurosceptic formations Libertas.cz and the Party of Free Citizens. At the same time some sitting MEPs elected in 2004 for new challenger parties created new parties as political vehicles to ensure their re-election in 2009: following differences with the Association of Independent Lists-European Democrats (SNKED) for whom she was elected an MEP in 2004, former diplomat Jana Hybášková created the European Democratic Party (EDS) in 2008, while in 2009 Jana Bobošíková, a former television presenter elected to the European Parliament on the Independent Democrats (NEZ) list in 2004, created the Sovereignty grouping which polled unexpectedly well in 2010 national parliamentary elections. ${ }^{36}$

\section{Conclusions}

This article has examined the nature of new parties - and the incentives and opportunities facing new parties - in the Czech Republic during the period of its apparent consolidation and stabilisation in years 1996-2010. As close examination of the Czech case shows, the 'newness' of new parties is neither given, nor conceptually or empirically straightforward. Party 'newness' can cover a range of phenomena including party origins, appeals and (non-)parliamentary status. Few 'new' parties, the Czech case suggests, will be new in all these respects. National party systems, it seems likely, will thus generate different but predictable distributions of 'new' parties. 
Following from this, it seems likely that patterns of (successful) new party development will vary markedly by type across national different contexts: successful new parties in the Czech Republic have generally programmatically been 'purifiers' and, in terms of their origins, breakaways from existing parties. A CEE polity with a more multi-dimensional party competition, a different configuration of second order elections or more loosely structured established parties could be expected to generate a different prevalent type of successful new party. This, in turn, highlights how different types of new party are facilitated (or blocked) by different mechanisms. Thus, while new first time contenders in the Czech Republic appear to have been highly sensitive to financial incentives, the development of breakaway parties seems conditioned more by favourable conjunctures in the party system, that lead established politicians to calculate that a new party venture could succeed. When such 'new' breakaway parties are launched, they often achieve relatively high level of electoral success compared to new parties with other types of origin. Similarly, while 'second order' elections generally play a role as an incubator for new parties, they vary in type incentives they offer with certain second order elections offering a more favourable environment for the development of certain new party types.

What do such patterns tell us about possible faultlines in the Czech party system that might have transmitted the shocks resulting in the 'political earthquake' of 2010? Of the two highly successful new parties that emerged in 2010, Public Affairs (VV) appears by far the more novel. As a breakaway, 'purifier' party TOP09 fits with an earlier, if rare, pattern of Czech party development, paralleled by the emergence of the Freedom Union (US) in 1997-8. Public Affairs, although loosely fitting with a broad pattern of resource mobilisation in which local independents' groupings gathering enough momentum to enter the national arena as a 'project of newness' parties is 
more unusual. As a new first time contender Public Affairs (VV) was exceptional in its immediate, huge electoral impact, which would not have been expected from earlier patterns of Czech new party emergence.

Although party system conjuncture was clearly related to its success, this distinctiveness seems explicable primarily in terms of a distinct pattern of resource mobilisation: the injection of significant private resources into an embryonic new minor party by a wealthy private individual, the businessman Vít Bárta (MFDnes 2011; Kmenta 2011). ${ }^{37}$ Although an unusual development in the Czech Republic, such a pattern of new party formation is familiar in contexts such as Latvia and Estonia - where the creation of 'pocket parties' by wealthy patrons is common (Sikk 2009, 2011; Bengtsson 2011) - and seems to fit with the broader trend towards what Hopkin and Paolucci (1999) term the 'business firm' model of party: the creation of new party organisation as loose, personality centred shell structure with neither meaningful membership nor administrative apparatus, replacing them instead with loose networks of sympathisers and links to commercial providers. ${ }^{38}$ Such parties typically lack any fixed ideology using marketing to create, rather simply sell programmes resulting in a vague reformist appeal akin to Sikk's 'project of newness'. As the paradigmatic case of Forza Italia shows, such groupings are often created and led by businesspeople, who have the personal resources and commercial know-how to implement this strategy most effectively. A businessperson-turned-party founder can also often credibly present themselves as an anti-political outsider offering a new way of 'doing politics'. 39

Public Affairs' early transformation by Vít Bárta into a vehicle for advancing his commercial interests in Prague; symbiotic relationship with his ABL security company in terms of organisation, personnel and financing; focus on building 
networks of registered sympathisers (veckáři) co-ordinated through internet and social media; and reliance on political marketing clearly meet the organisational criteria of the 'business firm' model. It is less clear, however, whether there was a distinct nexus between VV's organisational origins and strategy and its 'project of newness' appeal and, although de facto leader, Bárta studiously avoided the role of businessman turned anti-politician. ${ }^{40}$ The distinctness of Public Affairs - and anomalousness of its success viewed against the background of Czech new party development - nevertheless underlines the need to integrate patterns of organisational formation and resource mobilisation into typologies of party 'newness', hitherto focused on the nature of political appeals and extent to which founding elites are external or internal to established parties. It also suggests that, even if it does not ultimately reshape the party-political landscape, the 'political earthquake' election of 2010 may, nevertheless, represent a turning point in patterns of Czech new party formation. ${ }^{41}$

\section{Acknowledgements}

An earlier, shorter Czech language version of this paper was published in Sociologický časopis 47 (1). 


\section{References}

Aldrich, J. H., 1995. Why Parties? The Origin and Transformation of Political Parties in America. Chicago: University of Chicago Press.

Bengtsson, A., 2011, The Baltic Berlusconi: Recovery Takes Place in Silence, Baltic Worlds, 30 June. Available from: http://balticworlds.com/recovery-takes-place-insilence/ [accessed 20 October 2011].

Brown, G., 1997. Deliberation and Its Discontents: The Anti-Political Populism of H. Ross Perot. In A. Schedler ed. The End of Politics? Explorations into Modern Antipolitics. London and New York: Macmillan and St. Martins Press, 115-148. Deegan-Krause, K, 2006. Elected Affinities: Democracy and Party Competition in Slovakia and the Czech Republic. Stanford, CA: Stanford University Press.

Deegan-Krause, K., 2007. Populism and the Logic of Party Rotation in Postcommunist Europe. In O. Gyárfášová and G. Mesežnikov eds. Democracy and Populism in Central Europe: The Visegrad Elections and Their Aftermath. Bratislava: Institute for Public Affairs (IVO),141-156.

Deegan-Krause, K. 2010. Czech Election Update: Time for the Bigger Picture. Available at: http://www.pozorblog.com/2010/06/czech-election-update-time-for-thebigger-picture/ [accessed 1 July 2010].

Deegan-Krause, K. and Enyedi, Z., 2010. Agency and the Structure of Party Competition: Alignment Stability and the Role of Political Elites. Florence: European University Institute, Working Papers RCSAS 2010/09. Available at: http://cadmus.eui.eu/dspace/bitstream/1814/13133/1/RSCAS_2010_09.pdf [accessed 1 February 2010]. 
Deegan-Krause, K. and Haughton, T., 2010. A Fragile Stability: the Institutional Roots of Low Party System Stability in the Czech Republic 1990-2009. Politologicky casopis/Czech Journal of Political Science, 10 (3), 227-241

Demker, M., 2008. A New Era of Party Politics in a Globalised World: The Concept of the Virtue Party. Gothenburg: Quality of Government Institute, Working Paper 2008:20. Available at:

http://www.qog.pol.gu.se/working_papers/2008_20_Demker.pdf [accessed 20 January 2010].

Hanley, S. 2006. Europe and the Czech parliamentary elections of 2-3 June 2006, Falmer: Sussex European Institute, EPERN election briefing 27. Available at: http://www.sussex.ac.uk/sei/documents/epern_no_27.pdf [accessed 2 April 2010]. Hanley, S., 2010a. The consolidation of centre-right parties in the Czech Republic as an issue for comparative analysis. Politologický časopis, 17 (2), 115-132.

Hanley, S., 2010b. The Czech Republicans 1990-1998: Rise and Fall of Populist Radical Right Outsider Party. Paper presented at the workshop The Ambivalence of Populism: Threat or Corrective to Democracy?, Berlin, 5-6 August.

Hanley, S., (2011) Sovereignty: A Party to Watch, Dr Sean's Diary, 20 July. Available at: http://drseansdiary.wordpress.com/2011/07/20/czech-republicsovereignty-a-party-to-watch/ [accessed 10 November 2011].

Hanley, S., Szczerbiak, A., Haughton, T., and Fowler, B., 2008. Sticking together: Explaining Comparative Centre-Right Party Success in Post- Communist Central and Eastern Europe. Party Politics, 14 (4), 407-434.

Harmel, R.. 1985. On the study of new parties. International Political Science Review,6 (4), 403-418. 
Harmel, R. and Robertson, J. D. 1985. Formation and Success of New Parties: A Cross National Analysis. International Political Science Review, 6 (4), 501-23. Hopkin, J., 1999. Party formation and democratic transition in Spain: the creation and collapse of the Union of the Democratic Centre. Basingstoke: Palgrave Macmillan Press

Hopkin, J. and Paolucci, C. 1999. New Parties and the Business Firm Model of Party Organization: Cases from Spain and Italy, European Journal of Political Research 35 (3), 307-339.

Hug, S., 2001. Altering Party Systems. Strategic Behavior and the Emergence of New Political Parties in Western Democracies. Ann Arbor: The University of Michigan Press.

iDnes.cz, 2010. Př́běh Věcí veřejných: cesta od party aktivistů do vrcholné politiky, 7 June. Available at: http://zpravy.idnes.cz/pribeh-veci-verejnych-cesta-od-partyaktivistu-do-vrcholne-politiky-1i1-/domaci.asp?c=A100606_203840_domaci_iky [accessed 20 July 2010].

iHned.cz, 2011. 'Podnikatel Babiš chce dostat své hnutí ANO 2011 do Poslanecké sněmovny', 8 November. Available at: http://zpravy.ihned.cz/c1-53569270podnikatel-babis-chce-dostat-sve-hnuti-ano-2011-do-poslanecke-snemovny [accessed 18 November 2011].

Jüpter, P., 2008. Local Lists in the Czech Republic. In M. Reisner and E. Holtmann eds. Farewell to the Party Model? Independent Local Lists in East and West European Countries. Wiesbaden: Verlag für Sozialwissenschaften, 21-38.

Kitschelt, H., 1989. The Logics of Party Formation: Ecological Politics in Belgium and West Germany, Ithaca: Cornell University Press.

Kmenta, J., Superguru Bárta. Prague: JKM. 
Kneblová, E., 2009 Volební strategie Strany zelených ve volbách do Poslanecké sněmovny v roce 2006. Středoevropské politické studie, 9 (2-3), 181-209.

Kopeček, L., 2005a. Strana zelených'. In J. Malíŕ and P. Marek eds. Politické strany: vývoj politických stran a hnutí v českých zemích a Československu, II. díl 1938-2004. Brno: Doplněk, 1579-92

Kopeček, L., 2005b. Strana za životní jistoty’. In J. Maliř and P. Marek eds. Politické strany: vývoj politických stran a hnutí v českých zemích a Československu, II. díl 1938-2004. Brno: Doplněk, 1633-43.

Kopeček, L. and Pšeja, P., 2008. Czech Social Democracy and its cohabitation with the Communist Party: The story of a neglected affair. Communist and Postcommunist Studies, 41 (3), 317-338.

Kreuzer, M., 2009. How Party Systems Form: Path Dependency and the Institutionalization of the Post-War German Party System. British Journal of Political Science, 39 (4), 669-697.

Krouwel, A. and Bosch., O., 2004. Explaining the Emergence of New Parties: Cynical Citizens and the Rise of Populism. Paper prepared for the workshop Kwaliteit van het leven en politieke attitudes. Methodologische vraagstukken en empirische analyses, Antwerp, 27-28 May.

Lauder, S. (2010) ‘Supernova John’ Respekt Vol. 21, No. 8 (2010), pp. 18-20.

Lidové noviny. 2010. 'Nezůstal kámen na kameni'. 31 May, 1.

Linek, L. 2002. Co ne/dělat s teorií kartelové strany?. Politologická revue, 8 (2), 117 133.

Linek, L. and Lyons, P. 2007. What can Ecological Inference Tell Us about the Second-Order-Elections-Thesis in the Czech Republic and Slovakia?. In M. Marsh, S. Mikhaylov and H. Schmitt eds., European Elections after Eastern Enlargement. 
Preliminary Results from the European Election Study 2004. Mannheim: MZES, CONNEX, 327-369.

Linek, L. and Outlý, S., 2008 Czech Republic: Is it Possible to Buy Political Stability. In S. D. Roper and J. Ikstens eds. Public Finance and Post-Communist Party Development. Aldershot: Ashgate, 77-94

Lucardie, P., 2000. Prophets, Purifiers and Prolocutors: Towards a Theory on the Emergence of New Parties'. Party Politics, 6 (2), 175-185.

Mainwaring, S., España, A. and Gervasoni, C., 2009. Extra System Electoral Volatility and the Vote Share of Young Parties. Paper for the annual meeting of the Canadian Political Science Association, 28 May.

Mareš, M., 2003. Pravicový extremismus a radikalismus v ČR. Brno: Barrister and Principal.

Mareš, M., 2005a. Sdružení pro republiku-Republikanská strana Československa. In J. Malîr and P. Marek eds. Politické strany: vývoj politických stran a hnutí v českých zemích a Československu, II. dil 1938-2004. Brno: Doplněk, 1633-43

Mareš, M., 2005b. 'Nezávislé a „antistranické’ strany a hnutí'. In J. Malîr and P. Marek eds. Politické strany: vývoj politických stran a hnutí v českých zemích a Československu, II. dil 1938-2004. Brno: Doplněk, 1653-66.

Mareš, M. and Strmiska, M. 2005. Moravistické strany a hnutí. In J. Malíř and P. Marek eds. Politické strany: vývoj politických stran a hnutí v českých zemích a Československu, II. dil 1938-2004. Brno: Doplněk, 1615-1632.

Müller-Rommel, F. ed., 1989. New Politics in Western Europe: the rise and success of green parties and alternative lists. Boulder, Colorado and London: Westview Press. 
Panebianco, A. 1988. Political Parties: Organisation and Power. New York:

Cambridge University Press.

Pasquino, G., 2007. The Five Faces of Silvio Berlusconi: The Knight of Antipolitics', Modern Italy, 12 (1). 39-54

Pečínka, P. 2003. Jak Strana zelených svlékla starou kůži', Parlamentní zpravodaj 4, $31-36$

Pop-Eleches, G., 2010. Throwing Out the Bums Protest Voting and Unorthodox Parties after Communism. World Politics, 62 (2), 221-60.

Powell, E. N. and Tucker, J.T., 2009. New Approaches to Electoral Volatility:

Evidence from Postcommunist Countries. Unpublished paper dated 30 July. Available at: http://homepages.nyu.edu/ jat7/Powell_Tucker_Volatility.pdf [accessed 15

December 2009].

Pšeja, P., 2005. Stranický systém české republiky : politické strany a jejich vývoj 1989-1998. Brno: Centrum pro studium demokracie a kultury.

Pšeja, P. and Mareš, M., 2005. Malé strany liberální orientace. In J. Malíř and P. Marek eds. Politické strany: vývoj politických stran a hnutí v českých zemích a Československu, II. díl 1938-2004. Brno: Doplněk, 1667-1680.

Roberts, A. 2003. Demythologising the Czech Opposition Agreement. Europe-Asia Studies, 55 (8), 1273-1303.

Schedler, A., 1996. Anti-Political-Establishment Parties. Party Politics, 2 (3) 291-312. Schedler, A., 1997. Antipolitics - Closing or Colonizing the Public Sphere. In A. Schedler A. ed., The End of Politics? Explorations into Modern Antipolitics. London and New York: Macmillan and St. Martins Press, 1-20.

Sikk, A., 2005. How unstable? Volatility and the genuinely new parties in Eastern Europe. European Journal of Political Research. 44: 391-412. 
Sikk, A., 2009. Parties and Populism. London: UCL School of Slavonic and East European Studies Centre for Politics, Security and Integration Working Paper.

Available at: http://www.ssees.ucl.ac.uk/PartiesandPopulism.pdf [accessed 2 July 2010].

Sikk, A., 2011. Newness as a Winning Formula for New Political Parties. Party

Politics. Published online 21 March. DOI: 10.1177/1354068810389631.

Starostové a nezávislí. 2009. Kdo jsme. Available at:

http://www.starostove-nezavisli.cz/o-nas/kdo-jsme (accessed 1 April 2010)

Sikk, A. and Kangur, R., 2008. Estonia: The Increasing Costs and Weak Oversight of Party Finance. In S.D. Roper and J. Ikstens eds. Public Finance and Post-Communist Party Development Aldershot: Ashgate, 63-76.

Strana práv občanů - Zemanovci. n.d. Návrh programového prohlášení Strany práv

občanů - Zemanovci. Available at: http://www.spoz.cz/index.php/nase-

strana/program-spo [accessed 1 March 2010].

Suverenita. n.d. 'Kdo jsme: Suverenita - strana na obranu zajmů České republiky a jejích občanů'. Available at: http://www.suverenita.cz/kdo-jsme/historie [accessed 1 August 2010].

Szczerbiak, A. 2002. Poland's Unexpected Political Earthquake: The September 2001 Parliamentary Election. Journal of Communist Studies and Transition Politics, 18 (3), 41-76.

Tavits, M. 2008. 'Party Systems in the Making: The Emergence and Success of New Parties in New Democracies'. British Journal of Political Science, 38(1), 113:-133.

Učeň, P. 2007. Parties, Populism, and Anti-Establishment Politics in East Central Europe. SAIS Review, 27 (1): 49-62 
Učeň, P., Gyárfášová, O. and Krivý, V. 2005. Centrist Populism in Slovakia from the Perspective of Voters and Supporters. Slovak Foreign Policy Affairs, 2 (1), 28-47.

Willey, J. 1998. Institutional Arrangements and the Success of New Parties in Old Democracies. Political Studies, 46 (3), 651-68. 
Table 1: Sikk's typology of new parties' political appeals

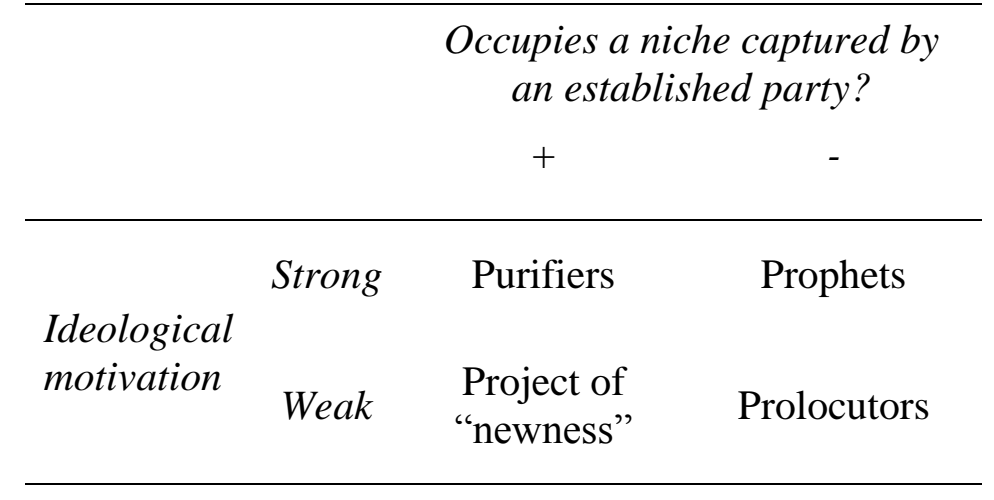

Source: Sikk (2011:3) 
Table 2: Political appeals of selected 'new' Czech parties 1996-2010

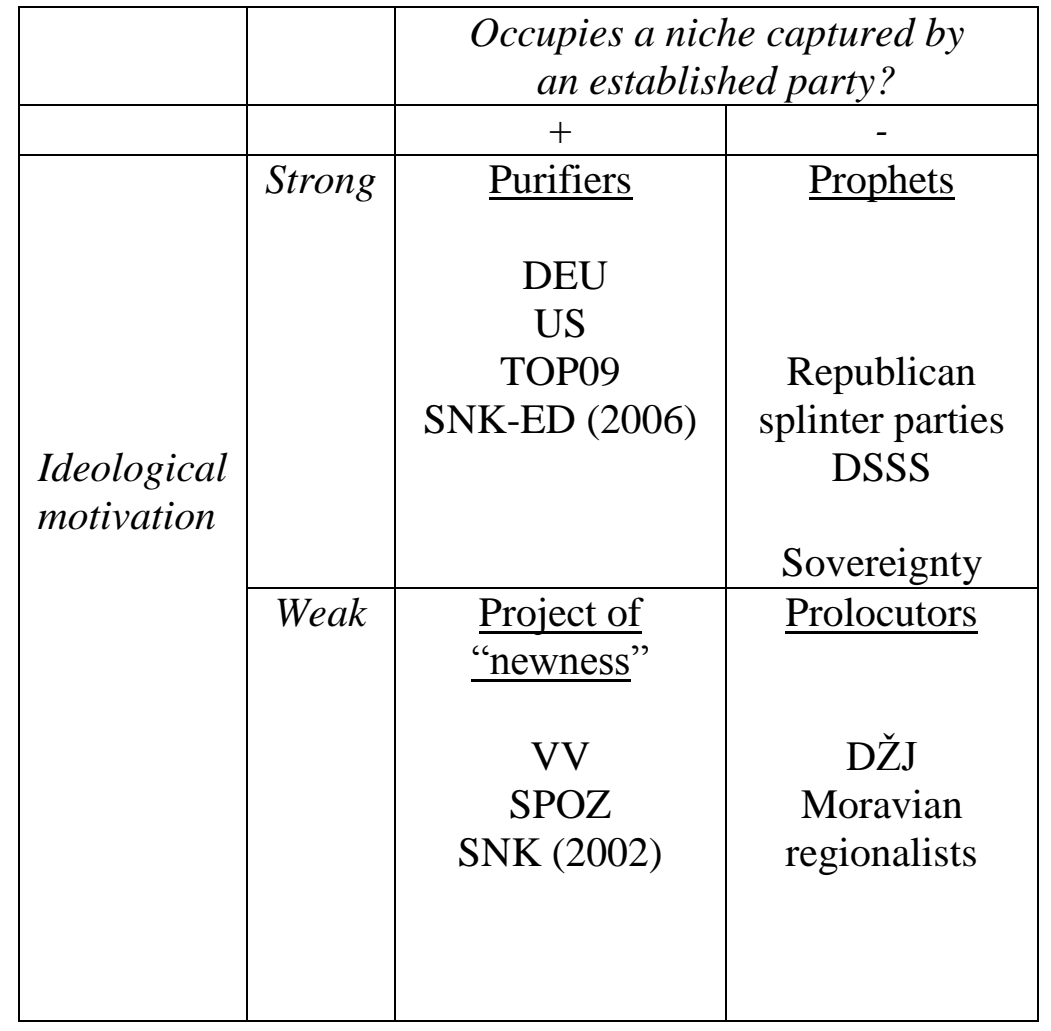


Figure 1

Volitility by type over time in the Czech Republic

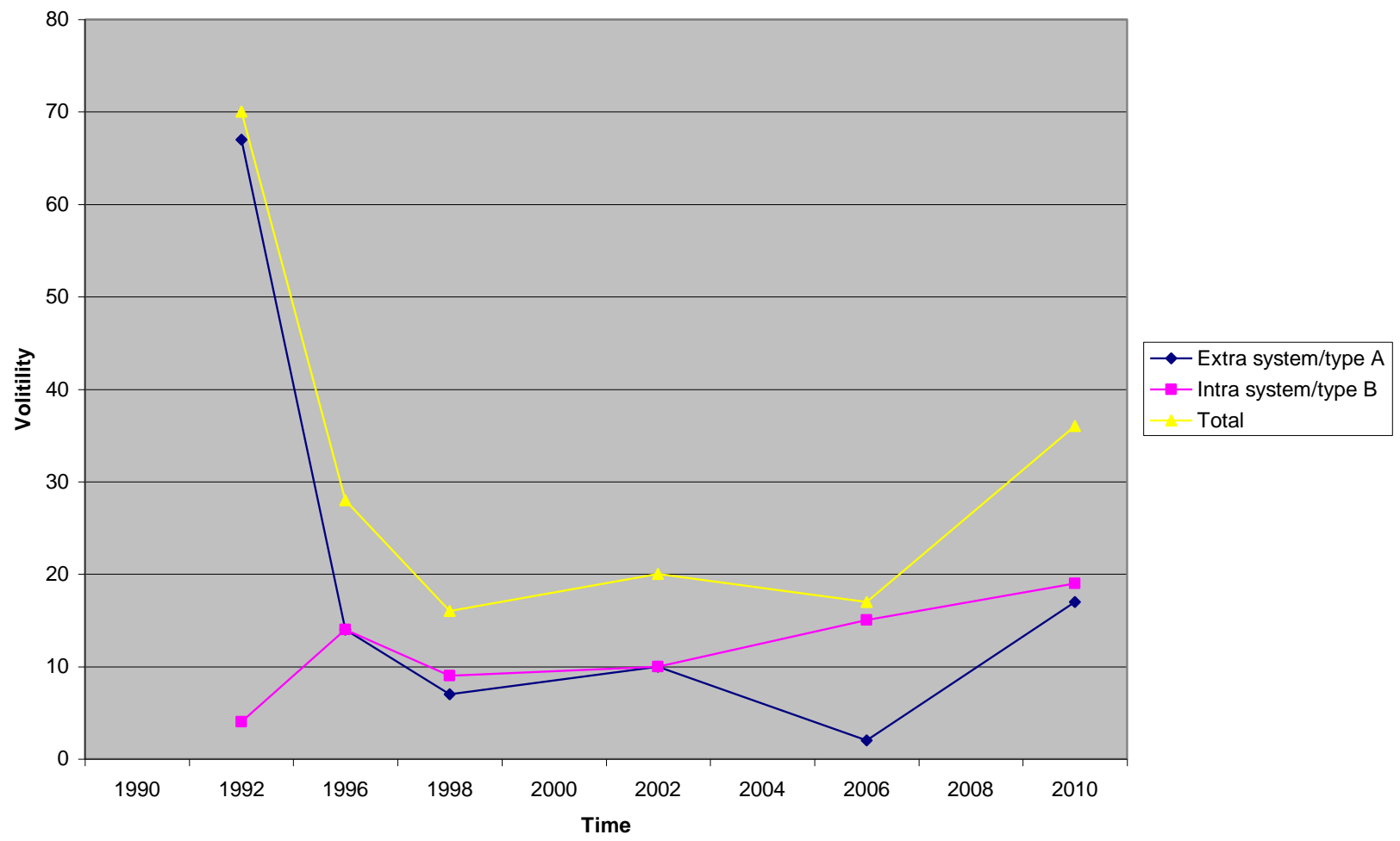

Source: Kevin Deegan-Krause www.pozorblog.com 
Figure 2 Votes for types of new party in elections to the Czech Chamber of deputies

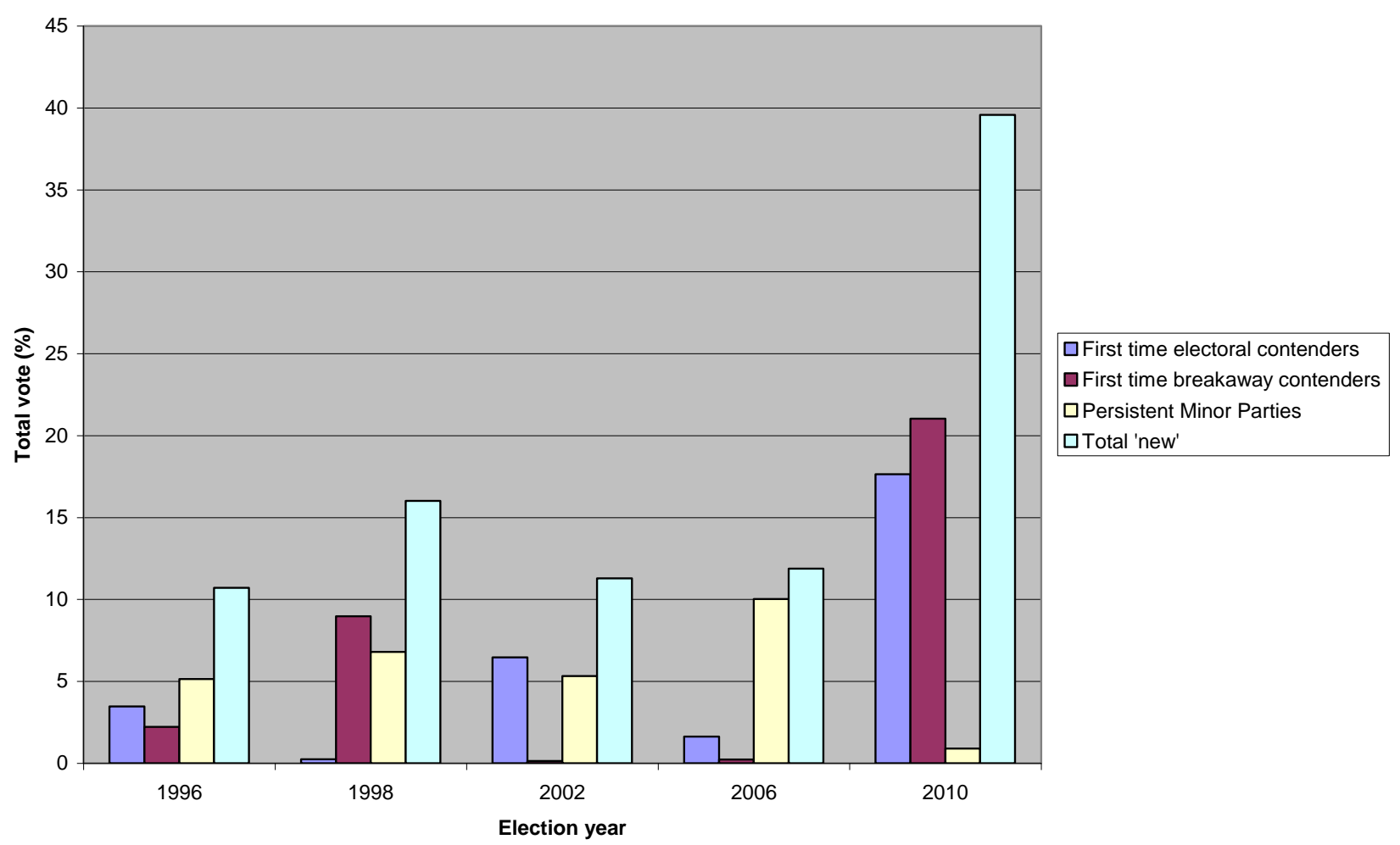

Source: Author's calculations based on Czech Central Electoral Commission 
Figure 3: Number of new parties contesting elections to the Czech Chamber of Deputies

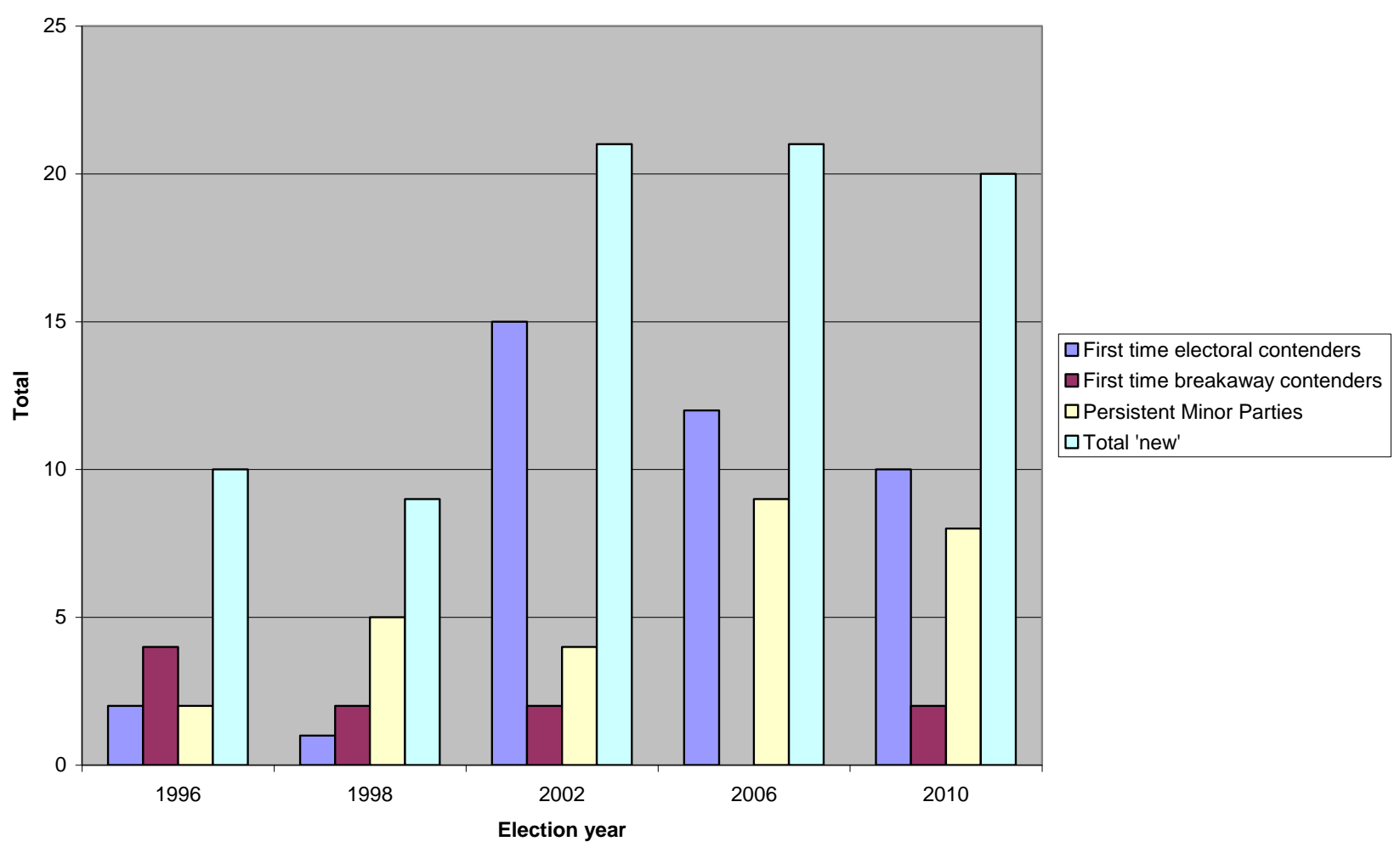

Source: Author's calculations based on Czech Central Electoral Commission 
Figure 4: New parties contesting elections to Czech Chamber of Deputies as a proportion of all parties contesting

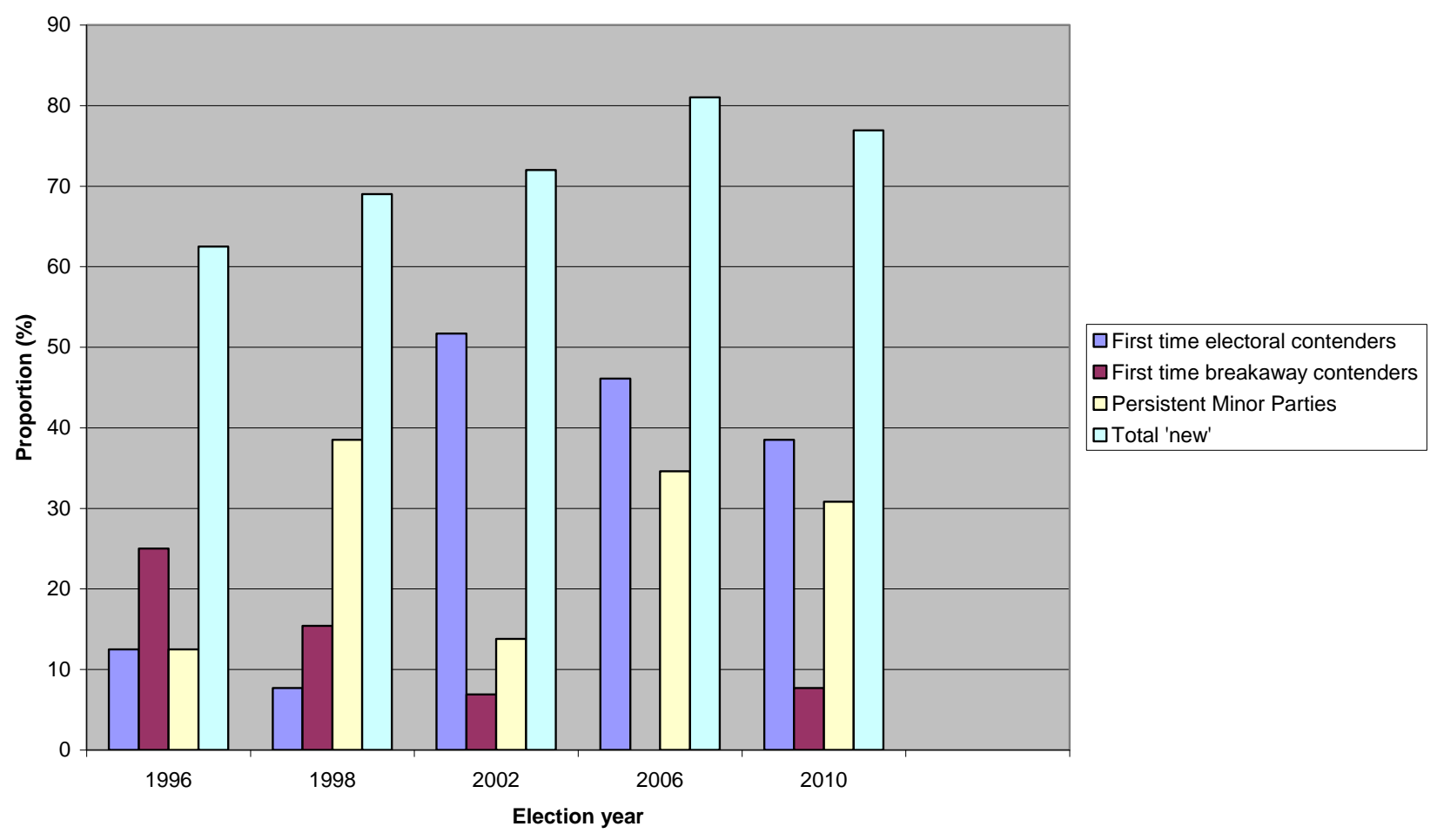

Source: Author's calculations based on Czech Central Electoral Commission

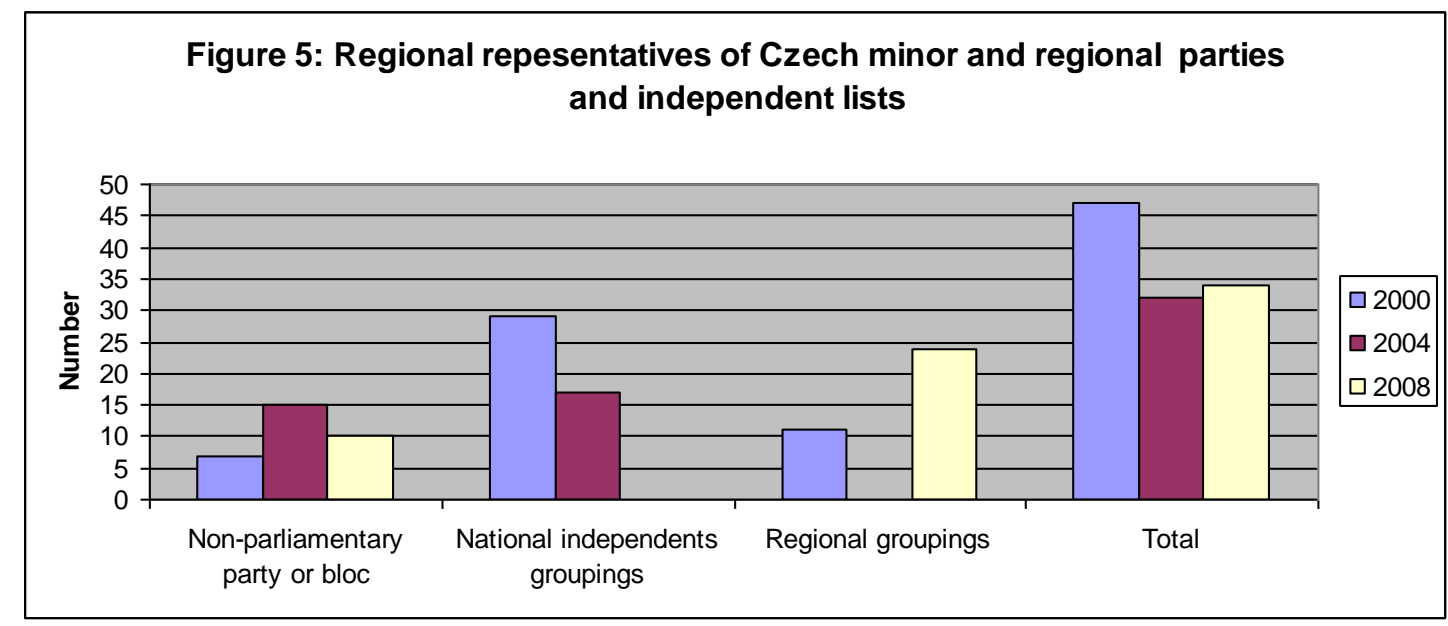

Source: Author's calculations based on Czech Central Electoral Commission 


\section{Appendix}

Tables 1-4: Categorisation of 'new' and established Czech parties

Key

$\mathrm{p}$ - persistent minor party

$\mathrm{n}$ - first time electoral contender

$\mathrm{e}$ - established party

$\mathrm{b}$ - breakaway party contesting election for the first time

1996 Election to Chamber of Deputies

\begin{tabular}{|c|c|c|c|c|}
\hline Party name (Czech) & Party name (English) & Vote & $\%$ & Category \\
\hline Důchodci za životní jistoty & Pensioners for a Secure Life & 187455 & 3.09 & $\mathrm{p}$ \\
\hline Svobodní demokraté-LSNS & $\begin{array}{l}\text { Free Democrats - Liberal } \\
\text { National Social Party }\end{array}$ & 124165 & 2.05 & $\mathrm{p}$ \\
\hline $\begin{array}{l}\text { Mor.nár.str.- } \\
\text { Hn.slezskom.sjed. }\end{array}$ & $\begin{array}{l}\text { Moravian National Party - } \\
\text { Movement for Moravian- } \\
\text { Silesian Unity }\end{array}$ & 16580 & 0.27 & $\mathrm{p}$ \\
\hline Demokratická unie & Democratic Union & 169796 & 2.8 & $\mathrm{n}$ \\
\hline Nezávislí & Independents & 30125 & 0.5 & $\mathrm{n}$ \\
\hline Česká pravice & Czech Right & 2808 & 0.05 & $\mathrm{n}$ \\
\hline $\begin{array}{l}\text { Občanská demokratická } \\
\text { strana }\end{array}$ & Civic Democratic Party & 1794560 & 29.62 & $\mathrm{e}$ \\
\hline Česká str.sociál.demokratická & $\begin{array}{l}\text { Czech Social Democratic } \\
\text { Party }\end{array}$ & 1602250 & 26.44 & $\mathrm{e}$ \\
\hline $\begin{array}{l}\text { Komunistická str.Čech a } \\
\text { Moravy }\end{array}$ & $\begin{array}{l}\text { Communist Party of Bohemia } \\
\text { and Moravia }\end{array}$ & 626136 & 10.33 & $\mathrm{e}$ \\
\hline Křest'.a dem.unie-Čs.str.lid. & $\begin{array}{l}\text { Christian Democratic Union - } \\
\text { Czechoslovak People's Party }\end{array}$ & 489349 & 8.08 & $\mathrm{e}$ \\
\hline Sdruž.pro rep.-Republ.str.Čsl. & $\begin{array}{l}\text { Association for the Republic } \\
\text { - Republican Party of } \\
\text { Czechoslovakia }\end{array}$ & 485072 & 8.01 & e \\
\hline $\begin{array}{l}\text { Občanská demokratická } \\
\text { aliance }\end{array}$ & Civic Democratic Alliance & 385369 & 6.36 & $\mathrm{e}$ \\
\hline Českomoravská unie středu & $\begin{array}{l}\text { Bohemian-Moravian Centre } \\
\text { Union }\end{array}$ & 27490 & 0.45 & $\mathrm{e}$ \\
\hline Levý blok & Left Bloc & 85122 & 1.4 & $\mathrm{~b}$ \\
\hline $\begin{array}{l}\text { Hn.samosp.M.aSl.- } \\
\text { Mor.nár.sjed. }\end{array}$ & $\begin{array}{l}\text { Movement for Self- } \\
\text { Governing Moravia and } \\
\text { Silesia - Moravian National } \\
\text { Unity }\end{array}$ & 25198 & 0.42 & $\mathrm{~b}$ \\
\hline Strana demokratické levice & Party of the Democratic Left & 7740 & 0.13 & $\mathrm{~b}$ \\
\hline
\end{tabular}


1998 Election to Chamber of Deputies

\begin{tabular}{|c|c|c|c|c|}
\hline Name (Czech) & Name (English) & Votes & $\%$ & Category \\
\hline $\begin{array}{l}\text { Důchodci za životní } \\
\text { jistoty }\end{array}$ & $\begin{array}{l}\text { Pensioners for a Secure } \\
\text { Life }\end{array}$ & 182900 & 3.06 & $\mathrm{p}$ \\
\hline Demokratická unie & Democratic Union & 86431 & 1.45 & $\mathrm{p}$ \\
\hline Strana zelených & Green Party & 67143 & 1.12 & $\mathrm{p}$ \\
\hline Nezávislí & Independents & 51981 & 0.87 & $\mathrm{p}$ \\
\hline $\begin{array}{l}\text { Moravská demokratická } \\
\text { strana }\end{array}$ & $\begin{array}{l}\text { Moravian Democratic } \\
\text { Party }\end{array}$ & 22282 & 0.37 & $\mathrm{p}$ \\
\hline $\begin{array}{l}\text { Česká strana národně } \\
\text { sociální }\end{array}$ & $\begin{array}{l}\text { Czech National Social } \\
\text { Party }\end{array}$ & 17185 & 0.29 & $\mathrm{p}$ \\
\hline $\begin{array}{l}\text { Občanská koalice- } \\
\text { Politic.klub }\end{array}$ & $\begin{array}{l}\text { Civic Coalition - } \\
\text { Political Club }\end{array}$ & 14788 & 0.25 & $\mathrm{n}$ \\
\hline $\begin{array}{l}\text { Česká str.sociálně } \\
\text { demokrat. }\end{array}$ & $\begin{array}{l}\text { Czech Social } \\
\text { Democratic Party }\end{array}$ & 1928660 & 32.31 & $\mathrm{e}$ \\
\hline $\begin{array}{l}\text { Občanská demokratická } \\
\text { strana }\end{array}$ & Civic Democratic Party & 1656011 & 27.74 & $\mathrm{e}$ \\
\hline $\begin{array}{l}\text { Komunistická str.Čech a } \\
\text { Moravy }\end{array}$ & $\begin{array}{l}\text { Communist Party of } \\
\text { Bohemia and Moravia }\end{array}$ & 658550 & 11.03 & e \\
\hline $\begin{array}{l}\text { Křest'.demokr.unie- } \\
\text { Čs.str.lid. }\end{array}$ & $\begin{array}{l}\text { Christian Democratic } \\
\text { Union - Czechoslovak } \\
\text { People's Party }\end{array}$ & 537013 & 9 & $\mathrm{e}$ \\
\hline $\begin{array}{l}\text { Sdruž.pro rep.- } \\
\text { Republ.str.Čsl. }\end{array}$ & $\begin{array}{l}\text { Association for the } \\
\text { Republic - Republican } \\
\text { Party of Czechoslovakia }\end{array}$ & 232965 & 3.9 & $\mathrm{e}$ \\
\hline Unie svobody & Freedom Union & 513596 & 8.6 & $\mathrm{~b}$ \\
\hline
\end{tabular}




\section{Election to Chamber of Deputies}

\begin{tabular}{|c|c|c|c|c|}
\hline Party name (Czech) & Party name (English) & Votes & $\%$ & Category \\
\hline Strana zelených (SZ) & Green Party & 112929 & 2.36 & $\mathrm{p}$ \\
\hline Strana za životní jistoty (SŽJ) & Party for a Secure Life & 41404 & 0.86 & $\mathrm{p}$ \\
\hline $\begin{array}{l}\text { Česká strana národně sociální } \\
\text { (ČSNS) }\end{array}$ & Czech National Social Party & 38655 & 0.81 & $\mathrm{p}$ \\
\hline $\begin{array}{l}\text { Moravská demokratická } \\
\text { strana (MDS) }\end{array}$ & Moravian Democratic Party & 12957 & 0.27 & $\mathrm{p}$ \\
\hline $\begin{array}{l}\text { Romská občanská iniciativa } \\
\text { ČR }\end{array}$ & $\begin{array}{l}\text { Roma Civic Initiative of the } \\
\text { CR }\end{array}$ & 523 & 0.01 & $\mathrm{p}$ \\
\hline $\begin{array}{l}\text { Strana demokrat.socialismu } \\
\text { (SDS) }\end{array}$ & $\begin{array}{l}\text { Party of Democratic } \\
\text { Socialism }\end{array}$ & 475 & 0 & $\mathrm{p}$ \\
\hline $\begin{array}{l}\text { Republikáni Miroslava Sládka } \\
\text { (RMS) }\end{array}$ & Miroslav Sládek Republicans & 46325 & 0.97 & $\mathrm{p}$ \\
\hline Česká pravice & Czech Right & 2041 & 0.04 & $\mathrm{p}$ \\
\hline Sdružení nezávislých & Association of Independents & 132699 & 2.78 & $\mathrm{n}$ \\
\hline Str.venkova-spoj.občan.síly & $\begin{array}{l}\text { Country Party - United Civic } \\
\text { Forces }\end{array}$ & 41773 & 0.87 & $\mathrm{n}$ \\
\hline Naděje & Hope & 29955 & 0.62 & $\mathrm{n}$ \\
\hline Pravý Blok PB & Right Bloc & 28163 & 0.59 & $\mathrm{n}$ \\
\hline Volba pro budoucnost ( $\mathrm{VpB})$ & Choice for the Future & 16730 & 0.35 & $\mathrm{n}$ \\
\hline Cesta změny (CZ) & Path of Change & 13169 & 0.27 & $\mathrm{n}$ \\
\hline Strana zdravého rozumu & Party of Common Sense & 10849 & 0.22 & $\mathrm{n}$ \\
\hline Akce za zruš.Senátu a proti t. & Action to Abolish the Senate & 9637 & 0.2 & $\mathrm{n}$ \\
\hline Balbínova poetická strana & Balbín Poetic Party & 9287 & 0.19 & $\mathrm{n}$ \\
\hline Humanistická aliance & Humanist Alliance & 8461 & 0.17 & $\mathrm{n}$ \\
\hline Národně demokratická strana & National Democratic Party & 5532 & 0.11 & $\mathrm{n}$ \\
\hline Demokratická liga & Democratic League & 4059 & 0.08 & $\mathrm{n}$ \\
\hline $\begin{array}{l}\text { České sociálně } \\
\text { demokrat.hnutí }\end{array}$ & $\begin{array}{l}\text { Czech Social Democratic } \\
\text { Movement }\end{array}$ & 602 & 0.01 & $\mathrm{n}$ \\
\hline Nové hnutí & New Movement & 139 & 0 & $\mathrm{n}$ \\
\hline Česká str.sociálně demokrat. & $\begin{array}{l}\text { Czech Social Democratic } \\
\text { Party }\end{array}$ & 1440279 & 30.2 & $\mathrm{e}$ \\
\hline $\begin{array}{l}\text { Občanská demokratická } \\
\text { strana (ODS) }\end{array}$ & Civic Democratic Party & 1166975 & 24.47 & $\mathrm{e}$ \\
\hline $\begin{array}{l}\text { Komunistická str.Čech a } \\
\text { Moravy (KSČM) }\end{array}$ & $\begin{array}{l}\text { Communist Party of Bohemia } \\
\text { and Moravia }\end{array}$ & 882653 & 18.51 & $\mathrm{e}$ \\
\hline Koalice KDU-ČSL, US-DEU & $\begin{array}{l}\text { Coalition of KDU-ČSL, US- } \\
\text { DEU }\end{array}$ & 680671 & 14.27 & $\mathrm{e}$ \\
\hline $\begin{array}{l}\text { Občanská demokratická } \\
\text { alliance (ODA) }\end{array}$ & Civic Democratic Alliance & 24278 & 0.5 & $\mathrm{e}$ \\
\hline Republikáni & Republicans & 6786 & 0.14 & $\mathrm{~b}$ \\
\hline
\end{tabular}


2006 Election to Chamber of Deputies

\begin{tabular}{|c|c|c|c|c|}
\hline Party (Czech) & Party (English) & Votes & $\%$ & Category \\
\hline Strana zelených & Green Party & 336487 & 6.29 & $\mathrm{p}$ \\
\hline NEZÁVISLÍ & Independents & 33030 & 0.61 & $\mathrm{p}$ \\
\hline Strana zdravého rozumu & Party of Common Sense & 24828 & 0.46 & $\mathrm{p}$ \\
\hline Pravý Blok & Right Bloc & 20382 & 0.38 & $\mathrm{p}$ \\
\hline Moravané & Moravians & 12552 & 0.23 & $\mathrm{p}$ \\
\hline Balbínova poetická strana & Balbín Poetic Party & 6897 & 0.12 & $\mathrm{p}$ \\
\hline Humanistická strana & Humanist Party & 857 & 0.01 & $\mathrm{p}$ \\
\hline Česká pravice & Czech Right & 395 & 0 & $\mathrm{p}$ \\
\hline SNK Evropští demokraté & $\begin{array}{l}\text { Association of Independent Lists - } \\
\text { European Democrats }\end{array}$ & 111724 & 2.08 & $\mathrm{p}$ \\
\hline $\begin{array}{l}\text { NEZ.DEMOKRATÉ } \\
\text { (předs.V.Železný) }\end{array}$ & Independent Democrats & 36708 & 0.68 & $\mathrm{n}$ \\
\hline Právo a Spravedlnost & Law and Justice & 12756 & 0.23 & $\mathrm{n}$ \\
\hline STRANA ROVNOST ŠANCÍ & Equal Opportunities Party & 10879 & 0.2 & $\mathrm{n}$ \\
\hline Národní strana & National Party & 9341 & 0.17 & $\mathrm{n}$ \\
\hline Koalice pro Českou republiku & Coalition for the Czech Republic & 8140 & 0.15 & $\mathrm{n}$ \\
\hline Koruna Česká (monarch.strana) & $\begin{array}{l}\text { Bohemian Crown (Monarchist } \\
\text { Party) }\end{array}$ & 7293 & 0.13 & $\mathrm{n}$ \\
\hline 4 VIZE-www.4vize.cz & 4 Vision -www.4vize.cz & 3109 & 0.05 & $\mathrm{n}$ \\
\hline Česká str.národ.socialistická & Czech National Socialist Party & 1387 & 0.02 & $\mathrm{n}$ \\
\hline Helax-Ostrava se baví & Helax-Ostrava Has Fun & 1375 & 0.02 & $\mathrm{n}$ \\
\hline Folklor i Společnost & Folklore and Society & 574 & 0.01 & $\mathrm{n}$ \\
\hline Liberální reformní strana & Liberal Reform Party & 253 & 0 & $\mathrm{n}$ \\
\hline České hnutí za národní jednotu & $\begin{array}{l}\text { Czech Movement for National } \\
\text { Unity }\end{array}$ & 216 & 0 & $\mathrm{n}$ \\
\hline Občanská demokratická strana & Civic Democratic Party & 1892475 & 35.38 & $\mathrm{e}$ \\
\hline Česká str.sociálně demokrat. & Czech Social Democratic Party & 1728827 & 32.32 & $\mathrm{e}$ \\
\hline Komunistická str.Čech a Moravy & $\begin{array}{l}\text { Communist Party of Bohemia and } \\
\text { Moravia }\end{array}$ & 685328 & 12.81 & $\mathrm{e}$ \\
\hline Křest'.demokr.unie-Čs.str.lid. & $\begin{array}{l}\text { Christian Democratic Union - } \\
\text { Czechoslovak People's Party }\end{array}$ & 386706 & 7.22 & e \\
\hline Unie svobody-Demokratická unie & $\begin{array}{l}\text { Freedom Union - Democratic } \\
\text { Union }\end{array}$ & 16457 & 0.3 & $\mathrm{e}$ \\
\hline
\end{tabular}


2010 Election to Chamber of Deputies

\begin{tabular}{|c|c|c|c|c|}
\hline Party (Czech) & Party (English) & Votes & $\%$ & Category \\
\hline Konzervativní strana & Conservative Party & 4232 & 0.08 & $\mathrm{p}$ \\
\hline Koruna Česká (monarch.strana) & $\begin{array}{l}\text { Bohemian Crown (Monarchist } \\
\text { Party) }\end{array}$ & 4024 & 0.07 & $\mathrm{p}$ \\
\hline Pr.Blok & Right Bloc & 24750 & 0.47 & $\mathrm{p}$ \\
\hline Moravané & Moravians & 11914 & 0.22 & $p$ \\
\hline Sdruž.pro rep.-Republ.str.Čsl. & $\begin{array}{l}\text { Association for the Republic- } \\
\text { Republican Party of Czechoslovakia }\end{array}$ & 1993 & 0.03 & $\mathrm{p}$ \\
\hline Česká str.národ.socialistická & Czech National Socialist Party & 1371 & 0.02 & $\mathrm{p}$ \\
\hline Humanistická strana & Humanist Party & 552 & 0.01 & $\mathrm{p}$ \\
\hline Česká strana národně sociální & Czech National Social Party & 295 & 0 & $\mathrm{p}$ \\
\hline Liberálové.CZ & Liberals.CZ & 260 & 0 & $p$ \\
\hline Dělnic.str.sociální spravedl. & Workers Party of Social Justice. & 59888 & 1.14 & $\mathrm{n}$ \\
\hline Věci veřejné & Public Affairs & 569127 & 10.88 & $\mathrm{n}$ \\
\hline Česká pirátská strana & Czech Pirate Party & 42323 & 0.8 & $\mathrm{n}$ \\
\hline Strana svobodných občanů & Party of Free Citizens & 38894 & 0.74 & $\mathrm{n}$ \\
\hline STOP & STOP & 3155 & 0.06 & $\mathrm{n}$ \\
\hline Suverenita-blok J.Bobošíkové & Sovereignty - Jana.Bobošíková Bloc & 192145 & 3.67 & $\mathrm{n}$ \\
\hline OBČANÉ.CZ & Citizens.CZ & 13397 & 0.25 & $\mathrm{n}$ \\
\hline Klíčové hnutí & Key Movement & 1099 & 0.02 & $\mathrm{n}$ \\
\hline EVROPSKÝ STŘED & European Centre & 522 & 0.00 & $\mathrm{n}$ \\
\hline NÁRODNÍ PROSPERITA & National Prosperity & 186 & 0 & $\mathrm{n}$ \\
\hline Komunistická str.Čech a Moravy & $\begin{array}{l}\text { Communist Party of Bohemia and } \\
\text { Moravia }\end{array}$ & 589765 & 11.27 & $\mathrm{e}$ \\
\hline Křest'.demokr.unie-Čs.str.lid. & $\begin{array}{l}\text { Christian Democratic Union - } \\
\text { Czechoslovak People's Party }\end{array}$ & 229717 & 4.39 & $\mathrm{e}$ \\
\hline Strana zelených & Green Party & 127831 & 2.44 & $\mathrm{e}$ \\
\hline Česká str.sociálně demokrat. & Czech Social Democratic Party & $\begin{array}{l}115526 \\
7\end{array}$ & 22,08 & $\mathrm{e}$ \\
\hline Občanská demokratická strana & Civic Democratic Party & $\begin{array}{l}105779 \\
2\end{array}$ & 20.22 & $\mathrm{e}$ \\
\hline TOP 09 & TOP 09 & 873833 & 16.7 & $\mathrm{~b}$ \\
\hline Strana Práv Občanů ZEMANOVCI & Citizens' Rights Party - Zemanites & 226527 & 4.33 & $\mathrm{~b}$ \\
\hline
\end{tabular}


Appendix table 5: Electoral support for types of 'new' party by election

\begin{tabular}{|l|r|r|r|r|r|}
\hline & 1996 & 1998 & 2002 & 2006 & 2010 \\
\hline First time electoral contenders & 3.46 & 0.25 & 6.46 & 1.62 & 17.64 \\
\hline First time breakaway contenders & 2.22 & 8.98 & 0.14 & 0.23 & 21.03 \\
\hline Persistent minor Parties & 5.14 & 6.8 & 5.32 & 10.02 & 0.9 \\
\hline Total 'new' & 10.71 & 16.01 & 11.28 & 11.87 & 39.57 \\
\hline
\end{tabular}

Appendix table 6: Numbers of 'new' parties contesting elections by type

\begin{tabular}{|l|r|r|r|r|r|}
\hline & 1996 & 1998 & 2002 & 2006 & 2010 \\
\hline First time electoral contenders & 2 & 1 & 15 & 12 & 10 \\
\hline First time breakaway contenders & 4 & 2 & 2 & 0 & 2 \\
\hline Persistent minor Parties & 2 & 5 & 4 & 9 & 8 \\
\hline Total 'new' & 10 & 9 & 21 & 21 & 20 \\
\hline
\end{tabular}




\section{Notes}

${ }^{1}$ Authors such as Mainwaring et al (2009) and Powell and Tucker (2009), who measure and compare within-system electoral volatility and extra-system volatility (shifts in electoral support from established parties to new challengers), conclude that, while high by international standards in the Czech Republic in 1996-2006 both forms of volatility were low compared to other Central and Eastern European states. Powell and Tucker also find that support for Czech new parties (as they define them) fell in every parliamentary election from 1996 to 2006.

${ }^{2}$ The number of effective parties is calculated using the Laakso-Taagepera method. The calculation of votes for post-2008 parties seems to include Sovereignty, the Citizens' Rights Party (SPOZ), the Workers' Party of Social Justice (DSSS), Občané.cz, the Party of Free Citizens (SOS) and the Czech Pirate Party (ČPS).The far-right DSSS, which polled 1.14 per cent in 2010, is, however, perhaps best regarded as the continuation of a party founded in 2004 .

3 The metaphor of the political 'earthquake' has also often used by political scientists to describe episodes of electoral change. Szczerbiak (2002), for example, characterises Poland's 2001 election - which saw extensive new party emergence and party replacement on the centre-right - in this way on the grounds that the result was unexpected and opened up opportunities for major party system restructuring. The Czech 2010 election meets these broad criteria. However, there has been little effort to define or conceptualise the term. 
${ }^{4}$ Sikk's (2005: 399) latter condition thus excludes as 'genuinely new parties' not only breakaway parties formed by the splits in existing parties, but any groupings involving the participation of 'former prime ministers or 'significant portions of ministers and members of parliament'.

${ }^{5}$ Other authors describe broadly the same phenomenon with different labels. Učeň (2007), for example, speaks of 'centrist populism' and Demker (2008) of 'virtue parties'.

${ }^{6}$ The development of parties and the party system have been key foci of Czech political science and there is a relatively large literature in both Czech and English on the subject as well as a number of reference works.

${ }^{7}$ A more restrictive view might interpret the Czech party system as having formed in 1990-1996 when the Czech Social Democratic Party (ČSSD) established itself as the main party of the centre-left in parliament. However, in my interpretation party system formation was completed earlier as ČSSD's status was already evident by 1994-5.

${ }^{8}$ I diverge from this slightly in classifying the Green Party (SZ) and the National Socialists as extra-parliamentary parties. Although both had representation in the Czech (and Czechoslovak) parliaments in 1992, this was gained by a short-lived ad hoc coalition, the Liberal Social Union and each clearly lacked sufficient support to cross the five per cent threshold independently.

9 Sikk (2005), for example, sees 'new' parties as first time contenders + extra parliamentary parties, Tavits (2008)as new contenders + new breakaway parties.

${ }^{10}$ Although authors disagree about whether 'breakaway' parties should be termed genuinely new, such 'overlapping' should not necessarily be regarded as making the categories derived from the literature incoherent. Indeed, such overlaps are common 
in most 'classically' constructed typologies - for example, the categories of 'Communist Parties' and 'Conservative Parties' 'overlap' because members of both groups are parties, but are meaningful and exclusive categories. There can, however, be advantages in fuzzier 'family resemblance' approaches party typologisation. For a discussin see Sikk (2009)

11 This pattern can also be founded, on a smaller scale, the Citizens' Rights Party (SPOZ) founded in 2009 by former Social Democrat Prime Minister Miloš Zeman and former leading Social Democrats. In the May 2010 SPOZ came close to crossing the five per cent threshold.

${ }^{12}$ The typology of party appeals does not, it should emphasised, seek to explain the specific success or failure of individual parties in specific elections, which are affected by a multitude of factors beyond the nature of their political appeals.

${ }^{13}$ Both US and TOP09 sought to project novelty and freshness in their political presentation and by introducing (minor) organisational innovations such as the recognition of sympathisers in party statutes.

${ }^{14}$ As with the prominent centre-right 'purifiers' both the Left Bloc (LB) and Party of the Democratic Left (SDL) were breakaway parties, having been founded by leading members of the KSČM.

${ }^{15}$ The two established parties on the centre-right, the Civic Democrats (ODS) and Christian Democrats (KDU-ČSL) offered distinct - and to some extent, diametrically opposed - policies: the former secular, pro-market and individualist, the latter stressing the need for a social market, the development of social policy, greater recognition of the Church, decentralisation, civil society development. There was thus much more limited competition between the two. 
16 It is also problematic to classify the appeal of the Civic Movement - Free Democrats (OH-SD), which emerged from Civic Forum in 1991 as a major governing party but had become a minor political actor by 1996. Although OH-SD policies overlapped with those of centre-right 'purifer' parties, its efforts to project itself as part of a distinct European liberal party family - including an ill-advised merger with the 'historic' Liberal Social National Party (LSNS) in 1996 - lead me, on balance, to classify it as a 'prophet' party.

${ }^{17}$ Other strongly eurosceptic groups like Party of Free Citizens (SSO), which define themselves as a conservative free market parties standing up for principles abandoned by the Civic Democrats, clearly classify as 'purifiers'.

${ }^{18}$ Sovereignty seems formally to begun as a coalition between the Politika 21 party founded by Bobošíková in 2006 and the tiny Common Sense Party (SZR). Although SZR contested the 2002 and 2006 elections to the Chamber of Deputies, I classify Sovereignty as new contender in 2010 as impetus and leadership clearly derived by Bobošíková's group.

${ }^{19}$ The inclusion of independents and (supposed) representatives of civil society is also characteristic of other 'new' party categories. For example, the Green Party offered places on its electoral list to signatories of the Brandýs Initiative manifesto in 2002, while Freedom Union recruited non-aligned academics and businesspeople as candidates.

${ }^{20}$ The European Democrats (ED) were a small liberal party formed in 2002 by the former Civic Democrat mayor of Prague Jan Kasal. Its support and organisation were concentrated in Prague, where it performed strongly municipal elections in November 2002. 
${ }^{21}$ A similar rationale was given for the merger of Politika 21 and the Common Sense Party (SZR) to form Sovereignty, although there is little evidence that SZR has a strong grassroots presence (Suverenita n.d).

${ }^{22}$ In the Czech case the main hurdle is the collection of a 1000 signature petition.

${ }^{23}$ It has been suggested that the comparative size of gap in funding for parliamentary and non-parliamentary parties was one the principal reasons for the stability of the Czech party system (Linek and Outlý 2008). However, this claim, however, appears not to have been comparatively tested. Countries with comparable electoral and funding thresholds and a similar disproportionality of funding such as Estonia do not seem to have undergone significant party system stabilisation in consequence (Sikk and Kangur 2008).

${ }^{24}$ Such unidimensionality may function, in particular, to close down the space for 'prophetic' parties making new ideological appeals, leaving new parties with a limited range of usable political appeals the most potent of which might to position themselves as 'purifiers'.

${ }^{25}$ Indeed, arguably the failures of the interwar Czech party system and, especially, the intense 'partification' of the state administration - in conjunction with the experience of communist one party rule - did as much to engender and reinforce Czech antipartyism, which still forms a strong current in public opinion.

${ }^{26}$. DEU merged with the Freedom Union in 2001.

${ }^{27}$ Under the new system parties fielding lists in all electoral districts had to pay fees totalling 200,000 Czech crowns (€8000 at current exchange rates), rather than deposits (forfeited by parties not entering parliament) of 1.6 million crowns $(€ 64,000)$. 
${ }^{28}$ However, Linek and Lyons' (2007) study of parliamentary and European elections in the Czech Republic and Slovakia finds that Second Order Election Thesis is mediated by regional context.

${ }^{29}$ No similar subsidy is paid to senators elected without a party nomination.

${ }^{30}$ Prague functions de facto as a fourteenth region, but is formally speaking a municipality with special powers. Election to Prague's elected city council take place in the same years as local, rather than regional election.

${ }^{31}$ The regional assemblies' size (45-65 members) does not impose a higher effective threshold.

${ }^{32}$ In 2000 regional elections national independents' groupings (SNK, Nezávislî) were the most successful type of challenger party. However, by 2008 such groups had, through a process of alliance-making and merge, evolved into nationally organised minor parties - Nezávislí became the basis of the Independent Democrats of Vladimír Železný, while SNK had merged with the European Democrats into a conventional party of the reformist liberal right - and were replaced in regional assemblies by a variety of purely regional groupings. As noted, following the 2008 regional election many coalesced into the national Mayors and Independents grouping that has allied itself with TOP09.

${ }^{33}$ However, given that the Czech Republic elects 22 MEPs and functions as a single electoral district in European elections reduces, the (mean) effective threshold is somewhat lower.

${ }^{34}$ The ULD was a coalition of small pro-market parties Civic Democratic Alliance (ODA), Freedom Union - Democratic Union (US-DEU), Path of Change (CZ) and the Liberal Reform Party (LIRA). 
35 These parties were Sovereignty (Suverenita), the Right Bloc, the European Democratic Party (EDS), Public Affairs (VV), Mayors and Independents, the Party of Free Citizens (SOS), SNK-ED and the Workers Party (DS). The far right DS was later dissolved by court order as unconstitutional, but later re-formed under a similar name. The Libertas.cz grouping narrowly fell below one per cent.

${ }^{36}$ The grouping's full name was initially Sovereignty - the Jana Bobošíková Bloc, amended in 2011 to Sovereignty - Bloc of the Future (SBB). It seems initially to have been coalition between the party founded by Bobošíková in 2006 (originally called Politika 21, later re-named Sovereignty) and the tiny, populist Common Sense Party (SZR).

${ }^{37}$ Bárta's goals in financing and developing Public Affairs seem to have been limited to municipal politics in Prague and other large urban centres and regions. VV's meteoric rise in national politics seems to have derailed these plans, subjecting Bárta to immense media scrutiny and leading him into an unplanned role as into an unplanned role as a government minister and national politician.

${ }^{38}$ Hopkin and Paolucci suggest that the 'business firm' model takes trend towards party professionalisation and disengagement from civil society to their logical end.

${ }^{39}$ Such appeals were central to, for example, the rise of business-politicians Silvio Berlusconi and Forza Italia in 1994 and Ross Perot's well supported third party campaign for the US presidency in 1992, when he polled $18.9 \%$ of the popular vote (Brown 1997; Pasquino 2007).

${ }^{40}$ Bárta was not a member of the party and formally took only secondary roles inVV as campaign manager and later MP and (briefly) minister. 
41 The continuation of this pattern is suggested, for example, by the creation in October 2011 by millionaire businessman Andrej Babiš of the anti-corruption, reform movement ANO 2011 which is to be registered as a political party to contest parliamentary elections in 2014 (iHned 2011). 